SRNL-STI-2010-00668

Revision 0

SRNL-STI-2010-00668

Rev.0

Keywords: technetium, cementitious materials.

saltstone, slag, reduction, $E$, oxidation- reduction potential

Retention: Permanent

\title{
Long-term Technetium Interactions with Reducing Cementitious Materials
}

Daniel I. Kaplan, Michael S. Lilley", Philip M. Almond, and Brian A. Powell ${ }^{\mathrm{a}}$

'Department of Environmental Engineering and Earth Sciences, Clemson University, Clemson, $\mathrm{SC}$

March 15, 2011

Savannah River National Laboratory Savannah River Nuclear Solutions, LLC Aiken, SC 29808

Prepared for the U.S. Department of Energy under contract number DE-AC09-08SR22470. 


\section{EXECUTIVE SUMMARY}

Technetium is among the key risk drivers at the Saltstone Facility. The way that it is immobilized in this cementitious waste form is by converting its highly mobile $\mathrm{Tc}$ (VII) form to a much less mobile Tc(IV) form through reduction by the cement's blast furnace slag. This report includes a review of published data and experimental results dealing with Tc leaching from Portland cement waste forms. The objectives for the literature study were to document previous reports of Tc interactions with slag-containing cementitious materials. The objectives for the laboratory study were to measure $\mathrm{Tc}$-saltstone $\mathrm{K}_{\mathrm{d}}$ values under reducing conditions. From the literature it was concluded:

1. Spectroscopic evidence showed that when Tc(IV) in a slag-cement was exposed to an oxidizing environment, it will convert to the more mobile $\mathrm{Tc}(\mathrm{VII})$ species within a short time frame, 2.5 years.

2. SRS saltstone will reduce $\mathrm{Tc}(\mathrm{VII})$ in the absence of $\mathrm{NaS}$ or sodium dithionite in a reducing atmosphere.

3. Only trace concentrations of atmospheric oxygen (30 to $60 \mathrm{ppm}_{2}$; Eh $120 \mathrm{mV}$ ) at the high $\mathrm{pH}$ levels of cementitious systems is required to maintain Tc as $\mathrm{Tc}(\mathrm{VII})$.

4. Experimental conditions must be responsible for wide variability of measured $\mathrm{K}_{d}$ values, such that they are either very low, $\sim 1 \mathrm{~mL} / \mathrm{g}$, or they are very high $\sim 1000 \mathrm{~mL} / \mathrm{g}$, suggesting that $\mathrm{Tc}(\mathrm{VII})$ or $\mathrm{Tc}(\mathrm{IV})$ dominate the systems. Much of this variability appears to be the result of experimental conditions, especially direct controls of oxygen contact with the sample.

5. A field study conducted at SRS in the 1980s indicated that a slag-saltstone immobilized Tc for 2.5 years. Below background concentrations of Tc leached out of the slagcontaining saltstone, whereas Tc leached out of the slag-free saltstone at the rate of nitrate loss. One possible explanation for the immobilization of Tc in this study was that the slag-saltstone maintained reducing conditions within the core of the 55-gallon sample, whereas in the small-scale lab experiments, where samples were crushed to $<1 \mathrm{~mm}$, oxygen diffused through the particles and reoxidize the slag during the contact period.

6. Present site specific reduction capacity value of $820 \mu \mathrm{eq} / \mathrm{g}$ is in the realm of literature values that were either measured or theoretically estimated based on thermodynamic calculations.

7. Almond and Kaplan (2011) measured desorption $\mathrm{K}_{\mathrm{d}}$ values from a Vault 4 saltstone core sample. Desorption leaching tests were conducted in a glovebag maintained at 30 to 60 ppm $\mathrm{O}_{2}$. A ground olive-colored saltstone sample, as compared to black monolith sample, was used in this study, indicating the sample had been exposed to $\mathrm{O}_{2}$, which is likely the cause for the lower then anticipated $\mathrm{K}_{\mathrm{d}}$ value measured, $139 \mathrm{~mL} / \mathrm{g}$.

Tc adsorption experiments were conducted under reducing conditions $\left(<0.5 \mathrm{ppm} \quad \mathrm{O}_{2(\mathrm{~g})}-585\right.$ $\mathrm{mV}, 2 \% \mathrm{H}_{2}, \mathrm{pH} 11.66$ ) and obtained $\mathrm{K}_{\mathrm{d}}$ values of $\sim 1000 \mathrm{~mL} / \mathrm{g}$ in a saltstone formulated with $45 \%$ slag (nominal concentration) and a $K_{d}$ of $10,000 \mathrm{~mL} / \mathrm{g}$ when the saltstone contained $95 \%$ slag. The $\mathrm{K}_{\mathrm{d}}$ values logarithmically increased from 1 day to 56 days, with little sorption generally occurring in the first eight days. Steady state had not been achieved during the initial 56 days. However, the slag -free cement control samples also had $K_{d}$ values near $1000 \mathrm{~mL} / \mathrm{g}$ and extremely low redox conditions, due to the $2 \% \mathrm{H}_{2}$ atmosphere.

A key concept that this literature review and the experimental results provide is that Tc immobilization is dependent on experimental conditions, specifically, the available oxygen that 
can oxidize technetium in a portland cement or saltstone-like monolith. The shrinking core model used in the saltstone performance assessment describes the existence of an oxidized outer layer of concrete surrounding a shrinking core of reducing intact saltstone. A sharp boundary between the two zones moves slowly inward, resulting in oxidation of Tc(IV). This work largely reinforced our conceptual model of the shrinking core model, but more importantly provided clarity regarding process kinetics, mechanisms, and input values for future detailed modeling. The shrinking core model in itself is devoid of geochemical mechanisms. This study provided more geochemical detail to this conceptual numerical model. 


\section{TABLE OF CONTENTS}

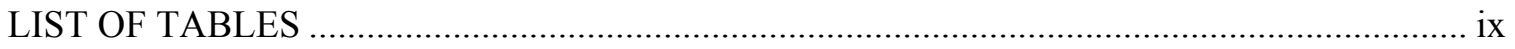

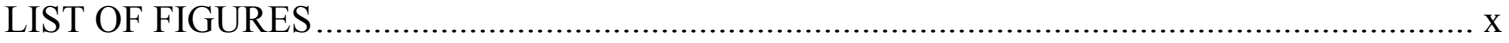

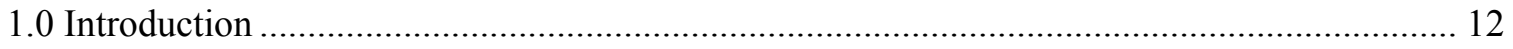

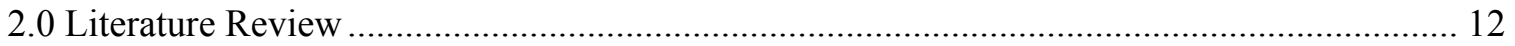

2.1 Technetium Interactions with Reducing Cementitious Materials ........................................ 12

2.1.1 LBNL Spectroscopy Measurements of Tc in SRS Saltstone ...................................... 12

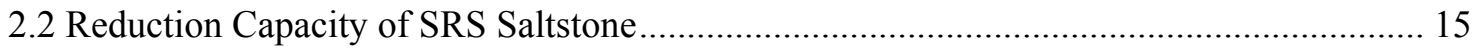

2.3 Discussion Points from Literature Review in Section 2.1 and 2.2 ................................. 17

3.0 Laboratory Study: Tc Sorption to Cementitious Materials under Reducing Conditions.......... 17

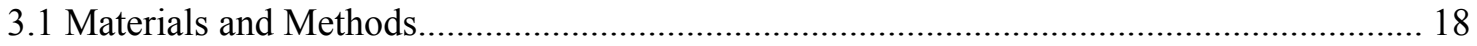

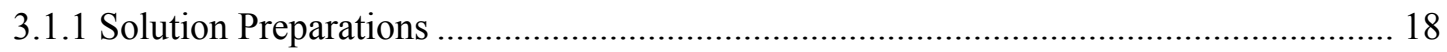

3.1.2 Cementitious and Saltstone Formulations Selected for Experiments............................ 19

3.1.3 Sorption Experiments under Anaerobic Conditions....................................................... 20

3.1.4 Examination of Sorption to Vial Walls for Solids and No Solids Controls .................. 21

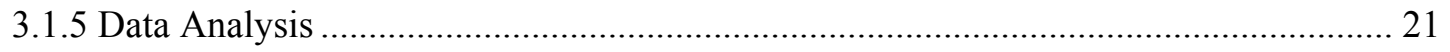

3.1.6 Experimental Methods for Long Term Saltstone Experiments .................................... 22

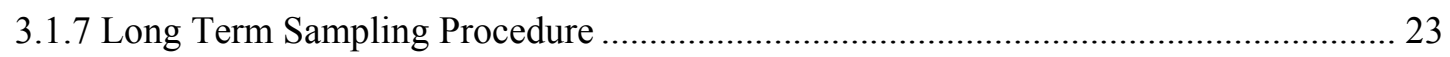

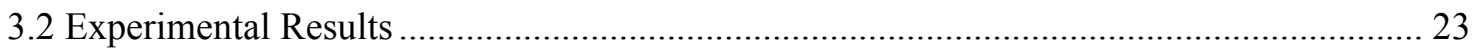

3.2.1 ${ }^{99} \mathrm{Tc}$ Sorption to Cementitious Materials under Reducing Conditions ........................... 24

3.2.2 Technetium Sorption to Vial Walls under Reducing Conditions................................... 26

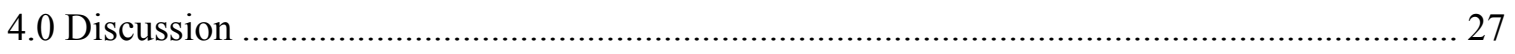

4.1 Tc Leaching Studies for Cementitious Waste Forms.................................................... 27

4.2 Tc Desorption $K_{d}$ Value from a Saltstone Core and other Cementitious Materials............. 31

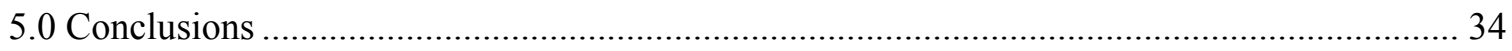

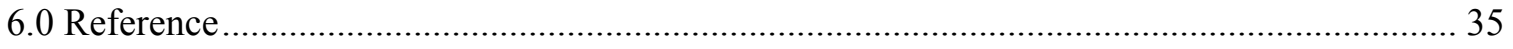




\section{LIST OF TABLES}

Table 1. Components of aqueous solutions (M) (Shuh et al. 2000). ${ }^{\mathrm{a}}$

Table 2. Speciation of Tc in saltstone samples during a 25-mo period. Sample identification is in Table 1. (Shuh et al. 2000).

Table 3. Components of aqueous solution (M) in second study conducted by Shuh et al. 2000). 14

Table 4. Speciation of Tc in sealed cement samples versus age in months. These samples were initially unsuccessfully reduced by alkaline $\mathrm{Na}_{2} \mathrm{~S}$ as a result of an experimental artifact (Shuh et al. 2000).

Table 5. Reduction capacity ( $\mu \mathrm{eq} / \mathrm{g}$ ) of solids using the Ce(IV)- Fe(II) colorimetric titration method with $0.5 \mathrm{~g}$ of solid sample (Roberts and Kaplan 2009)

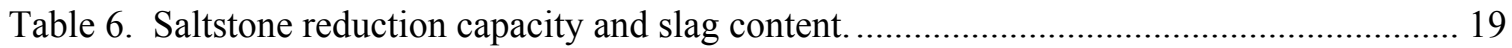

Table 7. Experimental matrix of sorption experiments under aerobic conditions....................... 21

Table 8. Experimental matrix of sorption experiments under aerobic conditions ........................ 23

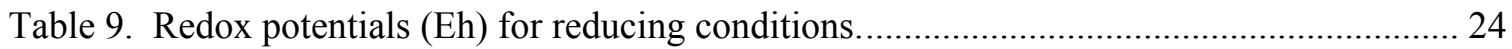

Table 10. Comparison of 1 and 4 Day TR547 and TR545 $\mathrm{K}_{\mathbf{d}}$ Values under reducing conditions from Initial and Long Term Experiments (Lilley 2010)..................................................... 26

Table 11. Formulations for saltstone waste forms used by Langton (1988). .............................. 29

Table 12. Sorption and diffusion measurements and calculated sorption coefficients for Tc(IV) and $\mathrm{Tc}(\mathrm{VII})$ with cementitious materials. 


\section{LIST OF FIGURES}

Figure 1. Screen capture of a typical ${ }^{99}$ Tc calibration curve using Thermo PlasmaLab software to control the data collection and analysis $\left(\mathrm{R}^{2}=0.999984\right.$, Intercept Concentration (Detection Limit) $=0.000013 \mathrm{ppb}$ )

Figure 2. Tc $K_{\mathbf{d}}$ values $(\mathrm{mL} / \mathrm{g})$ under reducing conditions. Tc $\mathrm{K}_{\mathbf{d}}$ values for various saltstone and concrete formulations measured after one, four, eight, twenty-two, and fifty-six day equilibration under reducing conditions. Total Tc concentrations in each system were $10 \mathrm{ppb}$ and $5 \mathrm{ppb}$ with each concentration set up in triplicate. The values expressed are averages of all six samples with the error bars representing the standard deviation. 25

Figure 3. Eh evolution with time as a function of blast furnace slag in cement (water/solid ration $=0.5$, cured at $25^{\circ} \mathrm{C}$. Cross hatching indicates variation in measured values (Atkins and Glasser 1992). 26

Figure 4. Fraction of aqueous Tc and I under reducing conditions in No-Solid Control samples (The iodine data is not of interest to this discussion).

Figure 5. Schematic diagram of slag saltstone lysimeter (Langton 1988). 30

Figure 6. Tc versus nitrate concentrations for slag- and cement-based saltstone lysimeters after 2.5 years in the field (Langton 1988). 30 


\section{LIST OF ABBREVIATIONS}

$\begin{array}{ll}\text { BFS } & \begin{array}{l}\text { Blast furnace slag } \\ \text { DDI }\end{array} \\ \text { Eh } & \begin{array}{l}\text { Redilled deionized water } \\ \text { ICP-MS }\end{array} \\ \text { Inductively coupled plasma mass spectrometry } \\ \text { QBNL } & \text { Lawrence Berkeley National Laboratory } \\ \text { SHE } & \text { Quality assurance/Quality control } \\ \text { SRNL } & \text { Standard hydrogen electrode } \\ \text { SRS } & \text { Savannah River National Laboratory } \\ \text { XAFS } & \text { Savannah River Site }\end{array}$




\subsection{Introduction}

This project consisted of a literature study and a laboratory study from a completed thesis study (Lilley 2010). The objectives for the literature study were to compare relevant research on Tc interactions with cementitious materials. The objectives for the laboratory study were 1) to measure Tc-saltstone $\mathrm{K}_{\mathrm{d}}$ values between 1- and 56-day contact periods under reducing conditions, and 2) to conduct long-term (weeks) Eh measurements in saltstone under reducing conditions.

\subsection{Literature Review}

\subsection{Technetium Interactions with Reducing Cementitious Materials}

\subsubsection{LBNL Spectroscopy Measurements of Tc in SRS Saltstone}

From a project conducted in the late 1990s, Lawrence Berkeley National Laboratory (LBNL) issued several reports and manuscripts on the subject of Tc interaction with saltstone (Shuh et al. 1994; Shuh et al. 2000; Allen et al. 1997; Lukens et al. 2005). These studies used X-ray absorption fine structure (XAFS) spectroscopy to determine the speciation of Tc in the solid phase. This is the best means available today to measure oxidation states of solid phase Tc. In these studies, they added $\mathrm{TcO}_{4}{ }^{-}$to an SRS saltstone formulation ${ }^{1}$ and followed the speciation of Tc over a 25-mo period. The cement was cast in polystyrene cuvettes, which were closed with vinyl tape and sealed inside two concentric, thin-walled polyethylene pages. Importantly, oxygen could diffuse at a slow rate into the cuvette. Oxygen would then have to diffuse into the saltstone material, and this should be a very slow process (shrinking core model), however, they saw appreciable oxidation of Tc in their samples. None of their samples were ground for the XAFS experiments. It is also important to note that alkaline $(1.8 \mathrm{M} \mathrm{NaOH}) \mathrm{Na}_{2} \mathrm{~S}$ was added to all the samples at time zero to insure that all the $\mathrm{TcO}_{4}{ }^{-}$was initially reduced by the saltstone. Therefore, their experiment was not designed to address the question, "Does saltstone reduce $\mathrm{TcO}_{4}{ }^{-?}$ ?" Instead it was designed to address the questions, "How rapidly does $\mathrm{Tc}(\mathrm{IV})$ reoxidize and what species of Tc exists in saltstone over time as it reoxidizes?

Four saltstone samples (46\% type F fly ash, 46\% BFS, $8 \%$ Portland cement) were created with the same solids compositions, but varying aqueous solution composition, whereby aqueous concentrations of nitrate/nitrite and phosphate were the independent variables in Table 1.

\footnotetext{
${ }^{1}$ Dry cement consisted of $46 \%$ fly ash, $46 \%$ BFS, and $8 \%$ Portland cement (Langton 1988).
} 
Table 1. Components of aqueous solutions (M) (Shuh et al. 2000). ${ }^{a}$

\begin{tabular}{cccc}
\hline Sample & $\mathbf{N O}_{3}{ }^{-}$ & $\mathbf{N O}_{2}{ }^{-}$ & $\mathbf{P O}_{4}{ }^{3-}$ \\
\hline Tc-1 & 2.0 & 0.62 & 0.12 \\
Tc-2 & none & none & 0.12 \\
Tc-3 & 2.0 & 0.62 & 0.2 \\
Tc-4 & none & none & 0.2 \\
\hline
\end{tabular}

a) In addition, each sample contained $0.35 \mathrm{M} \mathrm{NaAl}(\mathrm{OH})_{4}, 0.17 \mathrm{M} \mathrm{Na}_{2} \mathrm{CO}_{3}, 0.15 \mathrm{M} \mathrm{Na}_{2} \mathrm{SO}_{4}, 0.93 \mathrm{M}$ $\mathrm{NaOH}$, and $0.22 \mathrm{M} \mathrm{NaCl}$

Across the top of Table 2 we see months of exposure to air and within the body of the table we see the percentage of each Tc species. As noted earlier, initially all the Tc was reduced to $\mathrm{TcS}_{2}$, therefore all the Tc remained reduced in the saltstone either by the slag or by the added alkaline $\mathrm{Na}_{2} \mathrm{~S}$ (Table 2). $\quad \mathrm{Tc}^{\mathrm{IV}} \mathrm{S}_{2}$ is the least soluble form of Tc in Table 2, followed by $\mathrm{TcO}_{2^{-}}$ $\mathrm{xH}_{2} \mathrm{O}$, and $\mathrm{TcO}_{4}{ }^{-}$is soluble. With the exception of sample Tc-2, $\geq 25 \%$ of the $\mathrm{TcS}_{2}$ had oxidized to $\mathrm{TcO}_{4}{ }^{-}$. Therefore one important point we can take from this study is that

- $\mathrm{Tc}(\mathrm{IV})$ is converted to $\mathrm{Tc}(\mathrm{VII})$ as saltstone oxidizes. $\mathrm{TcO}_{2}$ hydrate appears to be an intermediate phase formed as a result of oxidation. $\mathrm{TcO}_{2}$ hydrate is also insoluble but further oxidizes to $\mathrm{Tc}(\mathrm{VII})$.

- The presence or absence of nitrate/nitrite does not appear to be correlated with the oxidation of Tc(IV). 
SRNL-STI-2010-00668

Revision 0

Table 2. Speciation of Tc in saltstone samples during a 25-mo period. Sample identification is in Table 1. (Shuh et al. 2000).

\begin{tabular}{lcccccc}
\hline \multicolumn{1}{c}{ Sample } & 0 & 3 & 9 & 12 & 16 & 25 \\
\hline $\mathrm{Tc}-1$ & $100 \%$ & $69 \%$ & $83 \%$ & $29 \%$ & $52 \%$ & $30 \%$ \\
$\mathrm{TcS}_{2}$ & $0 \%$ & $28 \%$ & $15 \%$ & $40 \%$ & $35 \%$ & $35 \%$ \\
$\mathrm{TcO}_{2} \cdot \mathrm{xH}_{2} \mathrm{O}$ & $0 \%$ & $4 \%$ & $3 \%$ & $32 \%$ & $13 \%$ & $33 \%$ \\
$\mathrm{TcO}_{4}^{-}$ & & & & & & \\
& & & & & & \\
$\mathrm{Tc}-2$ & $99 \%$ & $97 \%$ & $91 \%$ & $91 \%$ & $65 \%$ & $40 \%$ \\
$\mathrm{TcS}_{2}$ & $1 \%$ & $2 \%$ & $6 \%$ & $6 \%$ & $35 \%$ & $56 \%$ \\
$\mathrm{TcO}_{2} \cdot \mathrm{xH}_{2} \mathrm{O}$ & $1 \%$ & $1 \%$ & $2 \%$ & $3 \%$ & $0 \%$ & $4 \%$ \\
$\mathrm{TcO}_{4}^{-}$ & & & & & & \\
& & & & & & \\
$\mathrm{Tc}_{-} 3$ & $98 \%$ & $97 \%$ & $41 \%$ & $61 \%$ & $30 \%$ & $28 \%$ \\
$\mathrm{TcS}_{2}$ & $2 \%$ & $2 \%$ & $38 \%$ & $37 \%$ & $40 \%$ & $47 \%$ \\
$\mathrm{TcO}_{2} \cdot \mathrm{xH}_{2} \mathrm{O}$ & $1 \%$ & $1 \%$ & $21 \%$ & $2 \%$ & $29 \%$ & $25 \%$ \\
$\mathrm{TcO}_{4}^{-}$ & & & & & & \\
& & & & & & \\
$\mathrm{Tc}^{-4}$ & $96 \%$ & $93 \%$ & $73 \%$ & $85 \%$ & $37 \%$ & $27 \%$ \\
$\mathrm{TcS}_{2}$ & $4 \%$ & $5 \%$ & $27 \%$ & $13 \%$ & $42 \%$ & $42 \%$ \\
$\mathrm{TcO}_{2} \cdot \mathrm{xH}_{2} \mathrm{O}$ & $1 \%$ & $0 \%$ & $2 \%$ & $21 \%$ & $31 \%$ \\
$\mathrm{TcO}_{4}^{-}$ & $0 \%$ & $1 \%$ & & &
\end{tabular}

Shuh et al. (2000) conducted additional experiments where they attempted to reduce the saltstone with alkaline $\mathrm{Na}_{2} \mathrm{~S}$ solution, however the sulfide solution had partially oxidized therefore did not completely reduce the $\mathrm{TcO}_{4}{ }^{-}$to $\mathrm{TcS}_{2}$ at time zero (Table 3 and Table 4). This turned out to be a fortuitous mistake that provided important insight into saltstone reduction properties. The three samples created for this second study are described in Table 3 . The cement samples were placed in polystyrene cuvettes, sealed by filling the headspace with liquid epoxy, which formed an airtight seal with the cuvettes. The samples were then sealed in concentric polyethylene bags as in the first set of samples. The implications of potential $\mathrm{O}_{2}$ gas diffusion through the impermeable polystyrene cuvettes were not discussed.

Table 3. Components of aqueous solution (M) in second study conducted by Shuh et al. 2000)

\begin{tabular}{llll}
\hline Sample & $\mathbf{C l}^{-}$ & $\mathbf{N O}_{3}^{-}$ & $\mathbf{N O}_{2}^{-}$ \\
\hline Tc-A & 4 & None & None \\
Tc-B & None & 4 & None \\
Tc-C & None & None & 4 \\
\hline
\end{tabular}

In addition, each sample contained $4 \mathrm{M} \mathrm{NaOH}$.

The evolution of the Tc speciation for the sealed cement samples is provided in Table 4. These results are in marked contrast with those from the first experiment. In Table 4 only $40 \%$ of the Tc exists as $\mathrm{TcS}_{2}$, but more importantly, the fraction of $\mathrm{Tc}(\mathrm{IV})$ steadily increased with time. Since the $0.29 \mathrm{mM} \mathrm{Na}_{2} \mathrm{~S}$ had been completely oxidized, as evidenced by the presence of the 
partially reduced $0.02 \mathrm{mM} \mathrm{Tc}$ (the sulfate/sulfide has a lower standard reduction couple than the $\mathrm{Tc}(\mathrm{IV} / \mathrm{VII})$ couple), the reductant responsible for converting the $\mathrm{TcO}_{4}{ }^{-}$to $\mathrm{Tc}(\mathrm{IV})$ in these experiments is most likely BFS. The reductant can not be the $\mathrm{Na}_{2} \mathrm{~S}$ solution because it is obviously oxidized as evidenced by the fact that it did not completely reduce the $\mathrm{TcO}_{4}{ }^{-}$during the preparation of the samples. This argument is important to understand. If it had completely reduced the added $\mathrm{TcO}_{4}^{-}$, as was observed in Table 2 at month 0 , then this assertion could not be made. At time 0 mo, the samples contained between 24 to $27 \% \mathrm{TcO}_{4}{ }^{-}$(Table 4). Shuh et al. (2000) attributed the air leak to the different ways that the cuvettes were sealed with epoxy.

Table 4. Speciation of Tc in sealed cement samples versus age in months. These samples were initially unsuccessfully reduced by alkaline $\mathrm{Na}_{2} \mathrm{~S}$ as a result of an experimental artifact (Shuh et al. 2000).

\begin{tabular}{lccc}
\hline \multicolumn{1}{c}{ Sample } & 0 & 5 & 9 \\
\hline Tc-A & & & \\
$\mathrm{TcS}_{2}$ & $40 \%$ & $51 \%$ & $46 \%$ \\
$\mathrm{TcO}_{2} \bullet \mathrm{xH}_{2} \mathrm{O}$ & $34 \%$ & $29 \%$ & $42 \%$ \\
$\mathrm{TcO}_{4}^{-}$ & $26 \%$ & $20 \%$ & $12 \%$ \\
& & & \\
$\mathrm{Tc}-\mathrm{B}$ & & & \\
$\mathrm{TcS}_{2}$ & $40 \%$ & $44 \%$ & $51 \%$ \\
$\mathrm{TcO}_{2} \bullet \mathrm{xH}_{2} \mathrm{O}$ & $36 \%$ & $41 \%$ & $39 \%$ \\
$\mathrm{TcO}_{4}^{-}$ & $24 \%$ & $16 \%$ & $10 \%$ \\
& & & \\
$\mathrm{Tc}_{-} \mathrm{C}^{-}$ & & & \\
$\mathrm{TcS}_{2}$ & $40 \%$ & $37 \%$ & $41 \%$ \\
$\mathrm{TcO}_{2} \bullet \times \mathrm{H}_{2} \mathrm{O}$ & $33 \%$ & $38 \%$ & $42 \%$ \\
$\mathrm{TcO}_{4}^{-}$ & $27 \%$ & $25 \%$ & $17 \%$ \\
\hline
\end{tabular}

\subsection{Reduction Capacity of SRS Saltstone}

SRS saltstone nominally contains $45 \mathrm{wt}-\%$ slag. This slag provides a reduction capacity of nominally $820 \mu \mathrm{eq} / \mathrm{g}$ (Roberts and Kaplan 2009; Table 5). This method of measuring reduction capacity came from Angus and Glasser (1985). In going through the literature it is possible to compare the SRS values to those previously reported. 
Table 5. Reduction capacity ( $\mu \mathrm{eq} / \mathrm{g}$ ) of solids using the Ce(IV)- Fe(II) colorimetric titration method with $0.5 \mathrm{~g}$ of solid sample (Roberts and Kaplan 2009).

\begin{tabular}{cccc}
\hline Sample & $\begin{array}{c}\text { \% Blast } \\
\text { Furnace Slag }\end{array}$ & $\begin{array}{c}\text { Reduction Capacity } \\
\text { This Study } \\
(\boldsymbol{\mu e q} / \mathbf{g})\end{array}$ & $\begin{array}{c}\text { Reduction Capacity } \\
\text { Kaplan et al. (2008) } \\
(\boldsymbol{\mu e q} / \mathbf{g})\end{array}$ \\
\hline Saltstone TR437 & $45 \%$ & 849 & NA \\
Saltstone TR451 & $45 \%$ & 793 & NA \\
Saltstone TR547 & $45 \%$ & 607 & NA \\
Saltstone TR431 & $45 \%$ & NA & $821 \pm 5$ \\
Saltstone TR545 & $90 \%$ & 681 & NA \\
Portland Cement & $0 \%$ & 198 & NA \\
Class F Fly Ash & $0 \%$ & 299 & NA \\
Blast Furnace Slag & $100 \%$ & 819 & $832.4 \pm 5$ \\
Vault 2 Concrete & $10 \%$ & 178 & $239 \pm 31$ \\
Aged (30 yr.) Cement & $0 \%$ & NA & $86 \pm 10$ \\
\hline
\end{tabular}

It was established in Roberts and Kaplan (2009) that the value measured reported within their report, $819 \mu \mathrm{eq} / \mathrm{g}$, agreed well with those previously reported:

- $819 \mu \mathrm{eq} / \mathrm{g}$ (Roberts and Kaplan 2009)

- $832 \mu \mathrm{eq} / \mathrm{g}$ (Kaplan et al. 2008), and

- $817 \mu \mathrm{eq} / \mathrm{g}$ (Kaplan et al. 2005).

These values also agree well with a measurement conducted at LBNL using the same SRS slag and the method of Anus and Glasser (1985):

- $820 \mu \mathrm{eq} / \mathrm{g}$ (Lukens et al. 2005).

Angus and Glasser (1985) measured the reduction capacity of two slag-containing cements using the same analytical method as used by Robert and Kaplan (2009) and Lukens et al. (2005), the compositions of the cements were not specified:

- $1140 \mu \mathrm{eq} / \mathrm{g}$ (Ravenscraig slag; Angus and Glasser 1985) and

- $1100 \mu \mathrm{eq} / \mathrm{g}$ (Frodingham slag; Angus and Glasser 1985).

Finally, providing the most independent review of the reduction capacity values, Smith and Walton (1993) conducted thermodynamic calculations to estimate the reduction capacity of an $85 \%$ blast furnace slag $+15 \%$ ordinary Portland cement formulation. They based their input in these calculations on the sulfide, thiosulfide, Eh, and $\mathrm{pH}$, data from Angus and Glasser (1985) and their thermodynamic data came from cement phases and Tc species reported primarily from Criscenti and Serne (1990). They reported a reduction capacity of:

- $950 \mu \mathrm{eq} / \mathrm{g}$ (Frodingham slag; Smith and Walton 1993) 
Together these values provide a consistent description of the reduction capacity of reducing cement. The present site-specific value of $820 \mu \mathrm{eq} / \mathrm{g}$ appears to be in the realm of literature values that were measured or theoretically estimated.

\subsection{Discussion Points from Literature Review in Section 2.1 and 2.2}

1. Solid phase Tc(IV) in a slag-cement (Ordinary Portland Cement/Blast Furnace Slag) when exposed to an oxidizing environment will oxidize to the more mobile form $\mathrm{Tc}$ (VII) within a short time frame, $<2.5$ years (Shuh et al. 2000).

2. SRS saltstone will reduce $\mathrm{Tc}(\mathrm{VII})$ in the absence of $\mathrm{NaS}$ or sodium dithionite in a reducing atmosphere (Shuh et al. 2000).

3. Only trace concentrations of atmospheric oxygen (30 to $60 \mathrm{ppm} \mathrm{O}_{2}$; Eh $120 \mathrm{mV}$ ) at the high $\mathrm{pH}$ levels of cementitious systems is required to maintain Tc as $\mathrm{Tc}(\mathrm{VII})$ (Almond and Kaplan 2011).

4. Experimental conditions must be responsible for wide variability of measured $\mathrm{K}_{\mathrm{d}}$ values, such that they are either very low, $\sim 1 \mathrm{~mL} / \mathrm{g}$, or they are very high $\sim 1000 \mathrm{~mL} / \mathrm{g}$, suggesting that $\mathrm{Tc}(\mathrm{VII})$ or $\mathrm{Tc}(\mathrm{IV})$ dominate the systems. Much of this variability appears to be the result of experimental conditions, especially direct controls of oxygen contact with the sample. Experimental conditions (or formulations) are responsible for the uncertainties. As will be discussed in the experimental section (Section 3.0) we believe that much of this variability can be attributed to experimental conditions, especially direct controls of oxygen contact with the sample.

5. A field study conducted at SRS in the 1980s indicated that a slag-saltstone immobilized Tc for at least 2.5 years (Langton 1988). Below background concentrations of Tc leached out of the slag-containing saltstone, whereas Tc leached out of the slag-free saltstone at the rate of nitrate loss. One possible explanation for the immobilization of Tc in this study was that the slag-saltstone maintained reducing conditions within the core of the 55-gallon sample, whereas in the small-scale lab experiments, where samples were crushed to $<1 \mathrm{~mm}$, oxygen diffused through the particles and reoxidize the slag during the contact period (oxygen travel distance is $\sim \mathrm{D}_{\mathrm{d}} * \sqrt{\text { time }}$ ).

6. SRNL measurements of reducing capacity of $820 \mu \mathrm{eq} / \mathrm{g}$ using the Angus-Glasser method is in the realm of literature values that were either measured or theoretically estimated based on thermodynamic calculations.

\subsection{Laboratory Study: Tc Sorption to Cementitious Materials under Reducing Conditions}

These studies were conducted at Clemson University (Lilley 2010) and were designed to address the following objectives:

1. To compare long-term (56-day contact) Tc-saltstone $\mathrm{K}_{\mathrm{d}}$ values under reducing conditions, and

2. To conduct long-term (weeks) Eh measurements in saltstone under reducing conditions.

To put these measurements in context, the sorption of Tc to other cementitious materials were also measured. The cementitious materials used in this study were Vault 2, a 50-year-old cement, and a saltstone sample containing 90\% slag (TR545) and a sample containing 45\% slag (TR547). 
These materials will be discussed in more detail below. The sample closest to expected saltstone formulation was designated TR547 (45\% slag). The Vault 2 sample is a simulant cementitious material containing $17 \%$ slag and contains the formulation of the vault walls used to house the saltstone waste. The Aged Cement sample was a boring from a field pad (15cm to $30 \mathrm{~cm} \mathrm{depth)}$ that had been exposed to weather conditions for 50 years.

In this section the Materials and Methods will be presented then the Results.

\subsection{Materials and Methods}

The objectives for the laboratory study were:

1. To measure Tc-saltstone $K_{d}$ values between 1- and 56-day contact periods under reducing conditions, and

2. To conduct long-term (weeks) Eh measurements in crushed saltstone under reducing conditions.

They are taken from the thesis of Michael Lilley at Clemson University (Lilley 2010). Additional details, such as individual sample results, as opposed to average values, and numerous quality control sample results can be obtained from his thesis.(Lilley 2010) (In the thesis, the reader will also see results for $\mathrm{Pu}, \mathrm{I}$, and $\mathrm{Np}$ sorption to saltstone and SRS soil.)

\subsubsection{Solution Preparations}

A ${ }^{99} \mathrm{Tc}$ working solution was prepared by diluting a stock solution of ${ }^{99} \mathrm{Tc}$ (Isotope Products, Valencia, CA) in distilled-deionized water (distilled deionized (DDI) water Resistivity $>18$ $\mathrm{M} \Omega . \mathrm{cm}$ ). The oxidation state of Tc was not measured. However, based on the aqueous concentration in the DDI water solution, $\mathrm{Tc}(\mathrm{VII})$ is the expected oxidation state. The reduced $\mathrm{Tc}(\mathrm{IV})$ oxidation state would not be soluble under these conditions. The expected concentration of $950 \mathrm{ppb}$ based on the dilution was verified using liquid scintillation counting. The ${ }^{99} \mathrm{Tc}$ working solution was used to make $0.01,0.05,1,2,5$, and $10 \mathrm{ppb}$ standards by dilution using $2 \%$ $\mathrm{HNO}_{3}$. These standards were used to calibrate the Thermo Scientific X Series 2 inductively coupled plasma mass spectrometer (ICP-MS) for quantification of ${ }^{99} \mathrm{Tc}$. A screen shot of a representative calibration curve is shown in Figure 1. The instrument performance was monitored by interpolating between ${ }^{89} \mathrm{Y}$ and ${ }^{115} \mathrm{In}$ internal standards. The recovery of each sample during analysis was corrected based on the internal standard recovery. The internal standard recoveries remained within standard quality assurance/quality control (QA/QC) protocols for the instrument (between $80 \%$ and $120 \%$ ). 


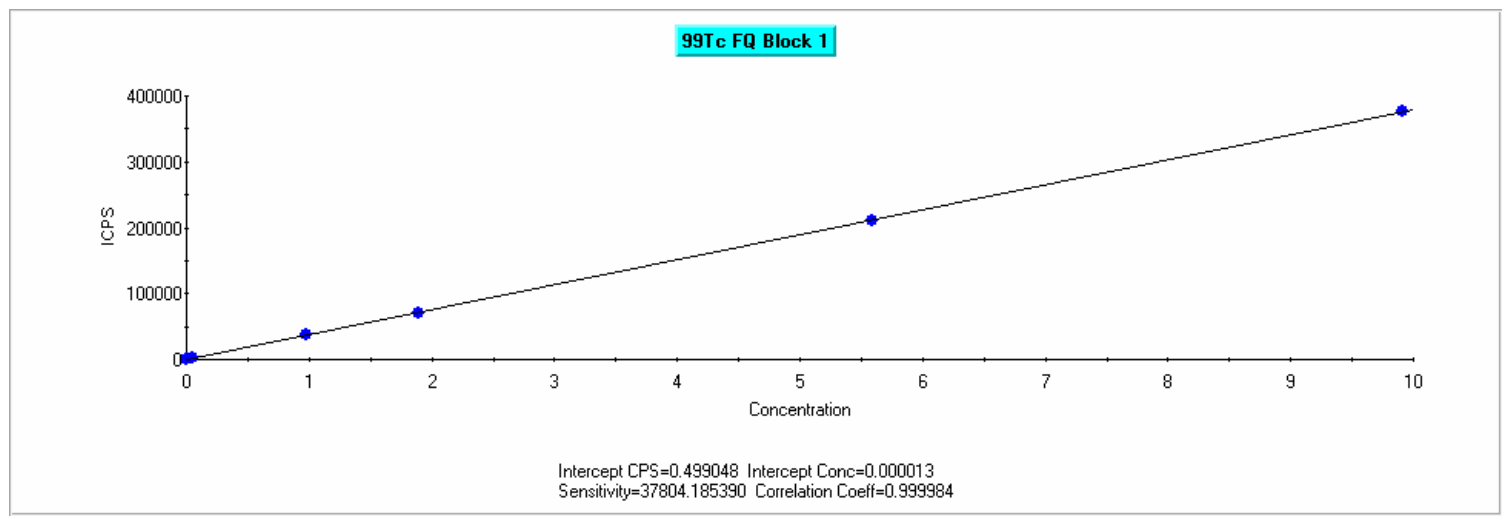

Figure 1. Screen capture of a typical ${ }^{99}$ Tc calibration curve using Thermo PlasmaLab software to control the data collection and analysis $\left(\mathrm{R}^{2}=\mathbf{0 . 9 9 9 9 8 4}\right.$, Intercept Concentration (Detection Limit) $=0.000013$ ppb).

\subsubsection{Cementitious and Saltstone Formulations Selected for Experiments}

There were four different cementitious formulations selected for this sorption study (Table 6). The first, referred to as Aged Cement, is a 50 year old sample that does not contain any reducing slag. The Vault 2 formulation is $17 \%$ reducing slag. The TR547 and TR545 saltstone formulations contain $45 \%$ and $90 \%$ reducing slag, respectively.

Table 6. Saltstone reduction capacity and slag content.

\begin{tabular}{lcc}
\hline Sample & $\begin{array}{c}\text { Reducing capacity } \\
(\boldsymbol{\mu e q} / \mathbf{g})\end{array}$ & $\begin{array}{c}\text { Slag } \\
\text { (wt-\%) }\end{array}$ \\
\hline Aged Cement & $85.5 \pm 10.1$ & 0 \\
Vault 2 & $239.8 \pm 31.1$ & 17 \\
TR547 & NA & 45 \\
TR545 & NA & 90 \\
Saltstone DDA stimulant* & $821.8 \pm 8.1$ & $23^{*}$ \\
Blast furnace slag* & $832.4 \pm 4.9$ & $100^{*}$ \\
\hline * First described in Kaplan et al. 2008. & \\
\hline
\end{tabular}

Preparation of Calcite Solution for Aerobic Conditions: Using a hot/stirring plate, $1.0 \mathrm{~L}$ of DDI water was heated to $3-10{ }^{\circ} \mathrm{C}$ above room temperature. Then $0.01 \mathrm{~g} \mathrm{CaCO}_{3}$ (EM Science, ACS grade) was added to the solution and the resulting suspension was mixed for 24 hours at the elevated temperature. The solution was then vacuum filtered through a $0.45 \mu \mathrm{m}$ filter to ensure no solid $\mathrm{CaCO}_{3}$ remained in solution.

Analysis of Tc on the ICP-MS required dilution in $2 \% \mathrm{HNO}_{3}$. This was prepared by adding $28 \mathrm{~mL}$ of Aristar Optima $\mathrm{HNO}_{3}$ from a clean graduated cylinder (designated to $2 \% \mathrm{HNO}_{3}$ ) into a $1 \mathrm{~L}$ volumetric flask (designated to $2 \% \mathrm{HNO}_{3}$ ) partially filled with DDI water, and then further diluted to volume. 


\subsubsection{Sorption Experiments under Anaerobic Conditions}

In order to examine the effects of reducing conditions of sorption of each isotope to the various saltstone samples, a series of sorption experiments were performed in an anerobic glovebox under a $2 \% \mathrm{H}_{2}(\mathrm{~g}) / 98 \% \mathrm{~N}_{2}(\mathrm{~g})$ atmosphere. Based on the measured $\mathrm{pH}$ and $\mathrm{E}_{\mathrm{H}}$ of these systems as discussed below, these systems were reducing and close to equilibrium with the $2 \%$ $\mathrm{H}_{2}(\mathrm{~g})$ atmosphere. (Theoretically, a $2 \% \mathrm{H}_{2}$ atmosphere will create a $-650 \mathrm{mV}$ atmosphere at equilibrium; based on the simplified $2 \mathrm{H}++2 \mathrm{e}-\Leftrightarrow \mathrm{H}_{2}(\mathrm{~g}): 2 \mathrm{H}++2 \mathrm{e}-\Leftrightarrow \mathrm{H}_{2}(\mathrm{~g})$. None of the cementitious samples were that low.) Therefore, they are expected to represent a lower end of the possible range for reducing conditions expected in the porewater available in reducing saltstone samples.

Preparation of Calcite for Reducing Conditions: Approximately $3.5 \mathrm{~L}$ of DDI water was boiled for 45 minutes. Argon was slowly bubbled through the water as it cooled. Once it cooled to below $50^{\circ} \mathrm{C}$, approximately $3 \mathrm{~g}$ of calcite was added. This solution mixed overnight under a continuous Ar flow. After 12 hours the solution was moved into an oxygen free glove bag for filtration as described above. After filtration, the calcite solution was moved into the glove box.

Preparation of Working Solutions under Reducing Conditions: The calcite and solid solutions were prepared in the glove box. The radionuclide working solutions were transferred to the glovebox and stirred open to the reducing atmosphere for at least 3 days. The concentrations of each isotope in the working solutions were measured to determine any change in the concentration due to evaporation while the solutions were equilibrating with the glovebox atmosphere.

Falcon BlueMax $15 \mathrm{~mL}$ polypropylene vials were labeled and weighed to within $0.001 \mathrm{~g}$ on a calibrated Sartorious LA 230S scale. The scale was then zeroed and $0.25+/-0.01 \mathrm{~g}$ of a given solid were added to each tube, and the weight was recorded to within $0.001 \mathrm{~g}$. For each of the four solids, three sets of triplicate samples were prepared. The three sets of samples were used to allow for experiments to be run with varying concentrations of ${ }^{99} \mathrm{Tc}$. Target initial concentrations for

${ }^{99} \mathrm{Tc}$ samples were $1 \mathrm{ppb}, 5 \mathrm{ppb}$, and $10 \mathrm{ppb}$. A set of no solids controls at initial concentrations of $1 \mathrm{ppb}$ and $10 \mathrm{ppb}$ for ${ }^{99} \mathrm{Tc}$ were also prepared by adding the calcite solution to pre-weighed, prelabeled centrifuge tubes as discussed above.

The solids were equilibrated with the calcite solution before spiking with the radionuclides. This was done by adding $10+/-0.1 \mathrm{~mL}$ of calcite solution to each tube, and recording the mass. The samples were then placed on a Thermo Scientific shaker overnight. After 24 hours, the solutions were allowed to settle for 1 hour. The $\mathrm{pH}$ was then measured and the samples were then centrifuged for 15 minutes at $8000 \mathrm{rpm}$ to further separate the solids. The aqueous phase was then decanted and $10+/-0.1 \mathrm{~mL}$ of calcite solution was added to each tube. The weight of the tube (labeled tube + solid + calcite solution) was measured to within $0.001 \mathrm{~g}$. During this washing process, the $\mathrm{pH}$ was monitored and held steady throughout the process. They ranged from 11-12 depending on the particular saltstone used. Details are presented in Lilley (2010).

The suspensions were spiked not only with ${ }^{99} \mathrm{Tc}$, but also with ${ }^{237} \mathrm{~Np},{ }^{242} \mathrm{Pu}$, and ${ }^{127} \mathrm{I}$ to final concentrations as shown in Table 7. Results from only the ${ }^{99} \mathrm{Tc}$ will be presented in this report. Given their low concentrations, ppb levels, it is anticipated that there will be minimal interactions between the various radionuclides influencing sorption. 
Table 7. Experimental matrix of sorption experiments under aerobic conditions

\begin{tabular}{ccc} 
Experiment & $\begin{array}{c}\text { Target Initial Concentration } \\
{ }^{99} \mathrm{Tc},{ }^{237} \mathrm{~Np},{ }^{242} \mathrm{Pu}\end{array}$ & Target Initial Concentration ${ }^{127} \mathrm{I}$ \\
\hline \hline Solids-Present & $1 \mathrm{ppb}$ & $100 \mathrm{ppb}$ \\
Solids-Present & $5 \mathrm{ppb}$ & $500 \mathrm{ppb}$ \\
Solids-Present & $10 \mathrm{ppb}$ & $1000 \mathrm{ppb}$ \\
Solids-Free & $1 \mathrm{ppb}$ & $100 \mathrm{ppb}$ \\
Solids-Free & $10 \mathrm{ppb}$ & $1000 \mathrm{ppb}$ \\
\hline
\end{tabular}

After spiking the radionuclides, a precalculated amount of $10 \mathrm{M} \mathrm{NaOH}$ was added to each sample to counter the acidity of the ${ }^{237} \mathrm{~Np}$ and ${ }^{242} \mathrm{Pu}$ spike solutions and the $\mathrm{pH}$ of one of the triplicate samples was measured to ensure the proper $\mathrm{pH}$ range was reached. The samples were then placed on an end-over-end shaker to mix at approximately $8 \mathrm{rpm}$. After 24 hours, the samples were removed from the shaker and the $\mathrm{pH}$ of each sample was measured using an Orion Ross semi-micro glass electrode calibrated against $\mathrm{pH} \mathrm{4,} \mathrm{7,} \mathrm{and} 10$ buffers (Thermo). The samples were then shaken and a transfer pipette was used to transfer $3.5 \mathrm{~mL}$ of a homogenous suspension to a $5 \mathrm{~mL}$ syringe. The solution was then passed through a $100 \mathrm{~nm}$ nylon syringe filter. The first $0.25-0.50 \mathrm{~mL}$ of filtrate was discarded and the remaining filtrate was collected in a clean polyethylene vial. After the 24 hour sampling event, the samples were put back on the shaker to mix for 3 additional days. On day 4, the above sampling procedure was repeated. The ${ }^{99} \mathrm{Tc}$ samples were analyzed on the Thermo Scientific ICP-MS using the standard setup and procedure which included a standard flow glass nebulizer and bulb spray chamber.

\subsubsection{Examination of Sorption to Vial Walls for Solids and No Solids Controls}

Once the 1 and 4 days samples were collected and run on the ICP-MS, it was necessary to determine the degree each radionuclide was sorbing to the vial walls. The remaining suspensions and controls were emptied into a waste container. Then $5 \mathrm{~mL}$ of the calcite solution was added to each vial using a calibrated pipette. The vials were sonicated for approximately one minute, and then emptied into the waste container. Another $5 \mathrm{~mL}$ of calcite solution was added for the second wash, and then discarded into the waste container. This procedure was expected to remove any soluble radionuclide from the system or radionuclide associated with colloidal particles. After each vial was washed, $10 \mathrm{~mL}$ of $2 \% \mathrm{HNO}_{3}$ was added using a calibrated pipette. The acid solution is expected to remove any Tc associated with the vial walls. This procedure has been shown to complete mass balances of $\mathrm{Pu}$ in similar sorption experiments using $\mathrm{Pu}$ (Powell et al. 2002). This process was performed for both the solid suspension and the no solids controls. The samples were then run on the ICP-MS to determine the concentration of ${ }^{99} \mathrm{Tc}$ sorbed to the vial walls.

\subsubsection{Data Analysis}

The solubilities of ${ }^{99} \mathrm{Tc}$ was calculated by using the formula:

$$
C_{\text {sol }}=\frac{C_{\text {ICP-MS }} * 10^{-6}\left(\frac{g_{\text {nuclide }}}{\mu g_{\text {nuclide }}}\right)}{M_{\text {nuclide }}}
$$


$C_{\text {sol }}=$ observed nuclide/compound solubility $\left(\mathrm{mol}_{\text {nuclide }} / \mathrm{kg}_{\text {solution }}\right)$

$C_{I C P-M S}=$ Aqueous concentration of nuclide from ICP-MS measurement (ppb,

$\mu \mathrm{g}_{\text {nuclide }} / \mathrm{kg}_{\text {solution }}$ )

$M_{\text {nuclide }}=$ molecular mass of nuclide $\left(\mathrm{g}_{\text {nuclide }} / \mathrm{mol}_{\text {nuclide }}\right)$

In order to determine the $\mathrm{K}_{\mathrm{d}}$ values, first need to determine the concentration on the solid by using:

$$
C_{\text {solid }}=\frac{\left[\frac{\left(C_{\text {stock }} * m_{\text {spike }}\right)}{\left(m_{\text {calcite }}+m_{\text {spike }}\right)}-C_{a q}\right] *\left(m_{\text {spike }}+m_{\text {calcite }}\right)}{m_{\text {solid }}}
$$

$\mathrm{C}_{\text {solid }}=$ calculated solid phase concentration of the nuclide associated with the saltstone $(\mathrm{ppb})$

$\mathrm{C}_{\text {stock }}=$ concentration of the nuclide stock solution (ppb)

$\mathrm{m}_{\text {spike }}=$ mass of nuclide spiked into the saltstone suspension $(\mathrm{g})$

$\mathrm{m}_{\text {calcite }}=$ total mass of calcite solution used in the saltstone suspension $(\mathrm{g})$

$\mathrm{C}_{\mathrm{aq}}=$ aqueous concentration of nuclide from ICP-MS measurement (ppb)

$\mathrm{m}_{\text {solid }}=$ mass of the saltstone used in the suspension $(\mathrm{g})$

The $\mathrm{K}_{\mathrm{d}}$ can be calculated using the equation:

$$
K_{d}=\frac{C_{\text {solid }}}{C_{a q}}
$$

$\mathrm{K}_{\mathrm{d}}=$ saltstone-water partitioning coefficient $\left(\mathrm{g}_{\text {solution }} / \mathrm{g}_{\text {solid }}\right.$, assuming density of $1.0 \mathrm{~g} / \mathrm{mL}$ traditional unit of $\mathrm{mL}_{\text {solution }} / \mathrm{g}_{\text {solid }}$ can be obtained)

\subsubsection{Experimental Methods for Long Term Saltstone Experiments}

After analyzing the results from the above saltstone experiments, it was apparent ${ }^{99} \mathrm{Tc}$ had not reached equilibrium after the 4 day sampling event (to be discussed in Section 3.2.1). It was deemed necessary to extend the sampling events over a longer period.

Falcon BlueMax 50mL polypropylene vials were labeled and weighed to within $0.001 \mathrm{~g}$ on a calibrated Sartorious LA 230S scale. The scale was then zeroed and $1.25+/-0.01 \mathrm{~g}$ of a given solid was added to each tube, and the weight was recorded to within $0.001 \mathrm{~g}$. For each of the four solids, two sets of triplicate samples were prepared. The two sets of samples were used to allow for experiments to be run with varying concentrations of each isotope. Target initial concentrations for ${ }^{99} \mathrm{Tc}$ samples were $5 \mathrm{ppb}$, and $10 \mathrm{ppb}$. A set of no solids controls at initial concentrations of $5 \mathrm{ppb}$ and $10 \mathrm{ppb}{ }^{99} \mathrm{Tc}$ were prepared by adding the calcite solution to preweighed, pre-labeled centrifuge tubes as discussed above.

The solids were equilibrated with the calcite solution before spiking with the radionuclides. This was done by adding $45+/-0.1 \mathrm{~mL}$ of calcite solution to each tube, and recording the mass. The samples were then placed on a Thermo Scientific shaker overnight. After 24 hours, the solutions were allowed to settle for 1 hour. The $\mathrm{pH}$ was then measured and the samples were 
then centrifuged for 15 minutes at $8000 \mathrm{rpm}$ to further separate the solids. The aqueous phase was then decanted and $50+/-0.1 \mathrm{~mL}$ of calcite solution was added to each tube. The weight of the tube (labeled tube + solid + calcite solution) was measured to within $0.001 \mathrm{~g}$. During this washing process, the $\mathrm{pH}$ was monitored and held steady throughout the process. They ranged from 11-12 depending on the particular saltstone used.

The resulting suspensions were then spiked with ${ }^{99} \mathrm{Tc}$ (and ${ }^{127} \mathrm{I}$, but the ${ }^{127} \mathrm{I}$ results are not reported here; see Lilley 2010). It is important to note that both isotopes were added to the same vial (see Table 8 ).

Table 8. Experimental matrix of sorption experiments under aerobic conditions

\begin{tabular}{lcc}
\hline Experiment & Initial Concentration ${ }^{99} \mathrm{Tc}$ & Initial Concentration ${ }^{127} \mathrm{I}^{(\mathrm{a})}$ \\
\hline Solids-Present & $5 \mathrm{ppb}$ & $50 \mathrm{ppb}$ \\
Solids-Present & $10 \mathrm{ppb}$ & $100 \mathrm{ppb}$ \\
Solids-Free & $50 \mathrm{ppb}$ & $50 \mathrm{ppb}$ \\
Solids-Free & $100 \mathrm{ppb}$ & $100 \mathrm{ppb}$ \\
(a) Iodine data is not reported here. Iodine spike information is presented to inform \\
reader that it was present in experiment.
\end{tabular}

This sample preparation was repeated to prepare anaerobic samples for use in the glovebox. The calcite used for these samples was prepared using the procedure previously described for anaerobic conditions.

\subsubsection{Long Term Sampling Procedure}

Both the aerobic and anaerobic samples were sampled using the method described in the initial saltstone experiments. However, the sampling timeline was much longer for these. Samples were taken at $1,4,8,22$, and 56 day intervals.

\subsection{Experimental Results}

Redox potential (Eh) and $\mathrm{pH}$ were measured in the test suspension 1 and 4 days after preparing the suspension in the anerobic glovebox (Table 9). The conditions within the glovebox are highly reducing, not changing very much from 1 day to 4 days. The Eh also generally decreased in a consistent trend with the amount of slag added. An important point to note here is that the No-Solids Control also had a very low redox, comparable to those with reducing cement. The fact that Eh decreases in a systematic manner with increasing amount of slag suggests that slag likely controlled Eh in the reducing cementitious materials, whereas the $\mathrm{H}_{2} / \mathrm{N}_{2}$ gases controlled the Eh in the Aged Cement ( $0 \%$ slag) and the Solids-Free Control. Significant ( $\mathrm{p} \leq$ $0.01, n=4)$ inverse correlations, existed between slag content and Eh with cementitious materials $(\mathrm{r}=-0.93,1$ day data, $\mathrm{P} \leq 0.01$; and $\mathrm{r}=-0.88$ for 4 day data, $\mathrm{P} \leq 0.05$; Table 9$)$. Had the $\mathrm{H}_{2} / \mathrm{N}_{2}$ gases been controlling the Eh, then there would not have been any correlation between slag content and Eh.

The Solids-Free Control therefore provides a test of whether the aqueous phase alone can promote the conversion of $\mathrm{Tc}(\mathrm{VII})$ to $\mathrm{Tc}(\mathrm{IV})$, sans solids to catalyze or promote the reduction reaction. Finally, by day 4, there was a near perfect inverse correlation between Eh and $\mathrm{pH}$, as 
thermodynamic theory would predict: $\mathrm{r}=-0.995$ for $\mathrm{n}=4, \mathrm{P} \leq 0.01$. This indicated that these two independent measurements were varying in a well behaved manner.

Table 9. Redox potentials (Eh) for reducing conditions.

\begin{tabular}{lccccc}
\hline Solids $^{\mathrm{a}}$ & & \multicolumn{2}{c}{1 day } & \multicolumn{2}{c}{4 day } \\
\cline { 3 - 6 } & $\begin{array}{c}\text { Slag } \\
(\%-\mathrm{wt})\end{array}$ & $\begin{array}{c}\text { Eh } \\
(\mathrm{mV})\end{array}$ & $\mathrm{pH}$ & $\begin{array}{c}\text { Eh } \\
(\mathrm{mV})\end{array}$ & $\mathrm{pH}$ \\
\hline Aged cement & 0 & -498 & 11.56 & -451 & 11.55 \\
Vault 2 concrete & 10 & -511 & 11.28 & -361 & 11.31 \\
TR547 & 45 & -585 & 11.66 & -498 & 11.70 \\
TR545 & 95 & -600 & 11.84 & -584 & 11.86 \\
No-Solids Control & 0 & -529 & 11.75 & -491 & 11.71 \\
\hline
\end{tabular}

${ }^{a}$ Suspensions were mixed in an anerobic glovebox under a $\mathrm{N}_{2}(\mathrm{~g}) / \mathrm{H}_{2}(\mathrm{~g})$ mixture. The $\mathrm{H}_{2}(\mathrm{~g})$ fraction averaged $1.5 \%$ over the course of the experiment. An oxygen gas monitor continuously read units of $0 \mathrm{ppm}$. Redox potentials were corrected to SHE. The aqueous phase was $\mathrm{Ca}(\mathrm{OH})_{2}$-saturated solution (a surrogate for cement leachate).

\subsection{1 ${ }^{99}$ Tc Sorption to Cementitious Materials under Reducing Conditions}

A plot of the $T c K_{d}$ values for the cementitious material under reducing conditions is shown in Figure 2 ( $\log$ y-axis). Sorption data after 1 day of equilibration for the Aged Cement and Vault 2 Cement are not shown because there was minimal sorption. This figure generally shows a steady increase in $K_{d}$ values for each cement and saltstone during the 56 days this study was conducted. Even after 56 days, almost 2 months, it is not clear that the experiments came to steady state. There is no evidence that this system has obtained steady state. It is possible that additional Tc removal from the aqueous phase would occur had the experiment been permitted to run longer.

The results in Figure 2 are consistent with Atkins and Glasser (1992) who demonstrate that the creation of a reducing environment in slag-containing grout (and therefore Tc removal from the aqueous environment) occurs over a period of months. They showed that the rate reducing grout creates a reducing environment depends on the amount of slag in the formula. They showed that a grout containing $85 \%$, and $70 \%$, and $50 \%$ would require about $<1 \mathrm{mo}, 3 \mathrm{mo}$, and $>18$ mo to create reducing conditions (Figure 3; Atkins and Glasser 1992). They attributed the rate limiting process to the hydration of the slag, which when hydrated releases $\mathrm{S}^{2-}$ into the aqueous phase, which in turn creates the reducing environment.

TR547 is most closely formulated to the saltstone presently being used at the Saltstone facility. Its $\mathrm{Tc} \mathrm{K}_{\mathrm{d}}$ was $\sim 1000 \mathrm{~mL} / \mathrm{g}$, whereas the controls had comparable values. Two points can be made from this observation. The first is that we can not be entirely sure what is promoting the reduction of $\mathrm{Tc}(\mathrm{VII})$ in the saltstone samples: is it the slag in the saltstone or the reducing conditions in the glovebox? The Eh data in Table 9 suggests that not only the $\mathrm{N}_{2}$ and $\mathrm{H}_{2}$ gases are controlling the redox of the suspension because the Eh values of the cementitious suspension are not the same as those of the control. In fact, as noted above, the Eh values decrease with increasing slag content, thereby demonstrating the impact of slag on controlling the system's Eh values. There is more than one chemical couple (e.g., $\mathrm{Fe}^{2+} / \mathrm{Fe}^{3+}$ ) controlling $\mathrm{Eh}$ in the 
cementitious systems we studied. Finally, it is possible, if not likely, that there is one process $\left(\mathrm{N}_{2} / \mathrm{H}_{2}\right.$ gases $)$ in the No-solids Control sample and separate ones in the four other cementitious materials.

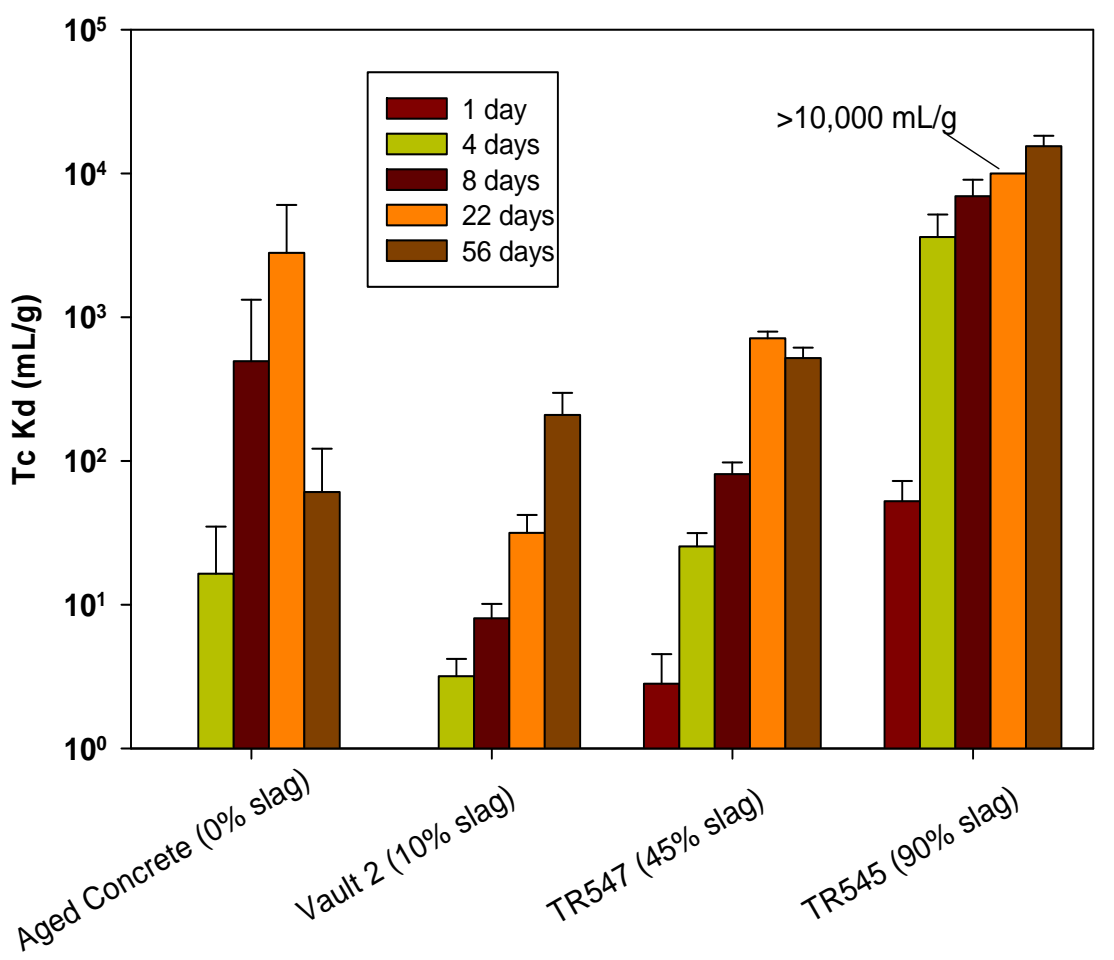

Figure 2. Tc $K_{d}$ values $(\mathrm{mL} / \mathrm{g})$ under reducing conditions. Tc $K_{d}$ values for various saltstone and concrete formulations measured after one, four, eight, twenty-two, and fiftysix day equilibration under reducing conditions. Total Tc concentrations in each system were $10 \mathrm{ppb}$ and $5 \mathrm{ppb}$ with each concentration set up in triplicate. The values expressed are averages of all six samples with the error bars representing the standard deviation. 
SRNL-STI-2010-00668

Revision 0

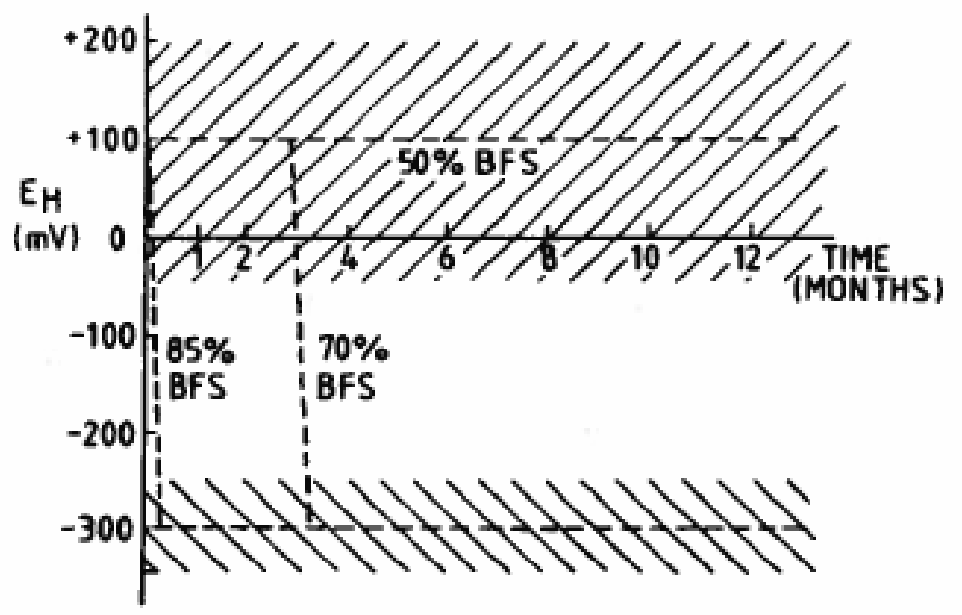

Figure 3. Eh evolution with time as a function of blast furnace slag in cement (water/solid ration $=0.5$, cured at $25^{\circ} \mathrm{C}$. Cross hatching indicates variation in measured values (Atkins and Glasser 1992).

The 1-day data presented in Figure 2 for the TR547 and TR545 saltstone samples were in general agreement with those from an initial short-term study conducted by Lilley (2010) (Table 10). By the 4-day sampling event, there was agreement between measured $K_{d}$ values between both experiments: the initial short-term trial and the long-term experiment. We present these data to provide confidence in the experimental approach and to show that the data are reproducible.

Table 10. Comparison of 1 and 4 Day TR547 and TR545 $K_{d}$ Values under reducing conditions from Initial and Long Term Experiments (Lilley 2010).

\begin{tabular}{lcccc}
\hline & \multicolumn{2}{c}{ Initial Experiment $^{\mathrm{c}}$} & \multicolumn{2}{c}{ Long Term Experiment $^{\mathrm{c}}$} \\
\cline { 2 - 5 } & 1 Day $_{\mathrm{d}}$ & 4 Day K $_{\mathrm{d}}$ & 1 Day $_{\mathrm{d}}$ & 4 Day K $_{\mathrm{d}}$ \\
\hline TR547 & $-3.45 \pm 0.89^{\mathrm{a}}$ & $24.89 \pm 17.03$ & $2.82 \pm 1.71$ & $25.43 \pm 6.03$ \\
TR545 & $39.47 \pm 23.9^{\mathrm{b}}$ & $4367.9 \pm 3658.5$ & $52.6 \pm 19.94$ & $3490 \pm 1526.1$ \\
\hline
\end{tabular}

${ }^{\mathrm{a}}$ Averages are of 9 samples with concentrations of 1, 5, and $10 \mathrm{ppb}$.

${ }^{\mathrm{b}} \mathrm{n}=6$; no $1 \mathrm{ppb}$ samples were used in average calculations due to large number of below detection values.

${ }^{\mathrm{c}}$ The Initial Experiment was conducted for 8 days and the Long Term

Experiment was conducted for 56 days, of which some of the data is presented in

Figure 2.

\subsubsection{Technetium Sorption to Vial Walls under Reducing Conditions}

A plot of the technetium (and iodine as part of another study not discussed here) in the aqueous fraction near 1.0 of each sample under reducing conditions is found in Figure 4, demonstrating near $100 \%$ recovery. At the 1 day sampling event, there were unexplained inconsistencies with both the Tc and I, which resulted in large standard deviations for each. Also, when analyzing the 22 day iodine samples, there was a problem with the Teflon nebulizer for 
both the No-Solids Control samples (as well as the saltstone and cement samples). Those data were lost and are not reported here. However, at the 4, 8, and 56 day sampling events, there was $100 \%$ mass recovery for both the Tc and I. This was also the case for the 22 day Tc samples. This shows there is not any significant sorption to the vial walls, so any loss of mass when solids are present is due to sorption to that particular solid phase.

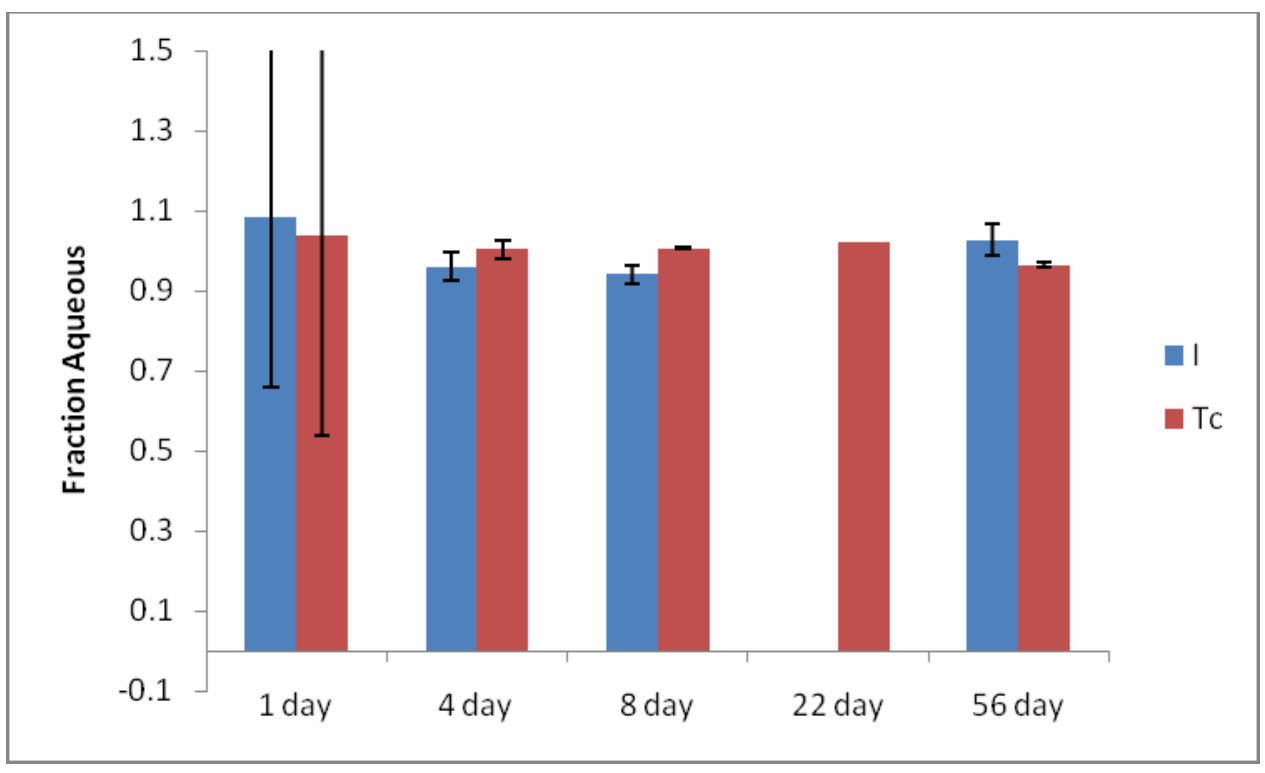

Figure 4. Fraction of aqueous Tc and I under reducing conditions in No-Solid Control samples (The iodine data is not of interest to this discussion).

\subsection{Discussion}

\subsection{Tc Leaching Studies for Cementitious Waste Forms}

There were a few studies involving Tc and slag-cementitious materials (Serne et al (1992), Langton 1988, Kaplan and Coates 2007, Kaplan et al. 2009; Brodda 1988; Tallent et al. 1988) (Table 12). Studies by Serne et al. (1992), Langton (1988), Brodda (1988) and Tallent et al. (1988) measured effective diffusion, $\mathrm{D}_{\mathrm{e}}$, (or its negative logarithm, leachability index) from monoliths of reducing grout using a standardized method, ANSI/ANS-16.1. As such they did not measure $K_{d}$ values. But in all cases they also calculated the $D_{e}$ of nitrate per ANSI/ANS-16.1. As a first approximation it is possible to estimate Tc $K_{d}$ values from $D_{e}$ values when nitrate $D_{e}$ values are also measured by assuming that nitrate does not sorb to sediments, i.e., it has a $\mathrm{K}_{\mathrm{d}}=0$ $\mathrm{mL} / \mathrm{g}$.

$$
D_{e}=D / R_{f}
$$

where $\mathrm{D}\left(\mathrm{cm}^{2} / \mathrm{s}\right)$ is diffusion in water (without cement) and $\mathrm{R}_{\mathrm{f}}$ is retardation factor $\left(\mathrm{cm} / \mathrm{s}_{\text {water }}\right.$ $\left./ \mathrm{cm} / \mathrm{s}_{\text {contaminant }}\right)$, which is related to $\mathrm{K}_{\mathrm{d}}(\mathrm{mL} / \mathrm{g})$ by: 


$$
\mathrm{R}_{\mathrm{f}}=1+\left(\rho_{\mathrm{b}} / \mathrm{n}\right) \mathrm{K}_{\mathrm{d}}
$$

where $\rho_{\mathrm{b}}$ is the bulk density $\left(\mathrm{g} / \mathrm{cm}^{3}\right), \mathrm{n}=$ the effective porosity $\left(\mathrm{cm}_{\text {pores }}^{3} / \mathrm{cm}^{3}\right.$ total $)$. For this calculation, it is assumed that $R_{f}$ of nitrate in cement equal 1 (and a $K_{d}=0 \mathrm{~mL} / \mathrm{g}$ ), meaning that nitrate moves, more specifically diffuses, at the same rate as water. Again, this is an approximation to help convert $D_{e}$ values to $K_{d}$ values and to permit comparing $D_{e}$ values with $K_{d}$ values, but technically the two values may be measuring two different phenomena.

$$
\mathrm{D}_{\mathrm{e}}(\mathrm{Tc}) / \mathrm{D}_{\mathrm{e}}\left(\mathrm{NO}_{3}\right)=\mathrm{R}_{\mathrm{f}}\left(\mathrm{NO}_{3}{ }^{-}\right) / \mathrm{R}_{\mathrm{f}}(\mathrm{Tc})=\mathrm{K}_{\mathrm{d}}\left(\mathrm{NO}_{3}\right) / \mathrm{K}_{\mathrm{d}}(\mathrm{Tc})
$$

Another important caveat with regards to $K_{d}$ values is that it is generally reserved for reversible adsorption reactions (Krupka et al. 1999). As such it should not be used for describing solubility conditions, which may exist in systems when estimated or calculated $\mathrm{K}_{\mathrm{d}}$ values were high, e.g. $>1000 \mathrm{~mL} / \mathrm{g}$. None of the studies in Table 12 conducted spectroscopy studies to confirm the oxidation state of Tc or to confirm whether sorption or precipitation occurred. For simplicity of presentation and ease for comparison, all the data in Table 12 was converted to $\mathrm{K}_{\mathrm{d}}$ values, but it is not meant to suggest a sorption mechanism.

Using the $\mathrm{D}_{\mathrm{e}}$ (or the leachability indexes) of the $\mathrm{Tc}$ and $\mathrm{NO}_{3}{ }^{-}$data presented in Table 12 and Equation 3, it is possible to estimate order-of-magnitude $\mathrm{K}_{\mathrm{d}}$ values. What we observe from Serne et al. (1992) is that Tc(VII) when added to Hanford reducing grout had relatively high (fast) $D_{e}$ values $\left(10^{-8} \mathrm{~cm}^{2} / \mathrm{s}\right.$; or using equation 3 , low $\mathrm{K}_{\mathrm{d}}$ values), whereas under identical experimental conditions (ANSI/ANS-16.1-1986) Langton (1988) reported low (slow) $\mathrm{D}_{\mathrm{e}}$ values using SRS saltstone $\left(10^{-12} \mathrm{~cm}^{2} / \mathrm{s}\right)$. In Serne et al. (1992), the Tc(VII) was added to two cement formulations (T106-AN 47.5\% slag and DSSF 47\% slag). They added Tc(VII) to the portland type I/II cement monoliths, then conducted leaching experiments, measuring the amount of Tc that leached into replaced volumes of Hanford groundwater or distilled water. There was little to no difference between the $\mathrm{D}_{\mathrm{e}}$ value of $\mathrm{NO}_{3}{ }^{-}$and $\mathrm{Tc}$, consequently Tc had low estimated $\mathrm{K}_{\mathrm{d}}$ values. No precautions were taken to exclude air from these experiments. Brodda (1988) and Tallent et al. (1988) also did $D_{e}$ measurements of slag-cements and reported that nitrate (indicative of a conservative tracer or of how fast water moves) leached about 100 times faster than Tc.

Langton (1988) measured $\mathrm{D}_{\mathrm{e}}$ for three NUCEM slag concentrations in SRS saltstone, $0 \%$, $15 \%$ and $26 \%$; the $\mathrm{D}_{\mathrm{e}}$ values were $10^{-9}, 10^{-12}$ and $10^{-12}$, respectively. The $\mathrm{NO}_{3}{ }^{-} \mathrm{D}_{\mathrm{e}}$ values for the $0 \%, 15 \%$ and $26 \%$ slag concentrations were $10^{-9}, 10^{-7}$ and $10^{-9}$, respectively. These $\mathrm{Tc} \mathrm{D}_{\mathrm{e}}$ values permit estimating $\mathrm{K}_{\mathrm{d}}$ values in the order of 1000 to $100,000 \mathrm{~mL} / \mathrm{g}$. These values suggest the presence of Tc(IV). No precautions were taken to exclude air from these experiments; they were conducted on the lab bench.

Gilliam et al. (1988) tested six different cementitious materials containing 20\% slag and reported similar Tc and nitrate leachability indices (determined from $\mathrm{D}_{\mathrm{e}}$ values) as Langton (1988) (leachability indexes are approximately equal to the $-\log$ of the $\mathrm{D}_{\mathrm{e}}$ ) (Table 12). They measured strongly reducing conditions of approximately $-250 \mathrm{mV}$ for the reducing cement and approximately $450 \mathrm{mV}$ for fly ash and the cement. The average ${ }^{99} \mathrm{Tc}$ leachability value was 10.50 \pm 0.5 for the six reduction cementitious materials. The average comparable nitrate leachability value was $7.30 \pm 0.10$. Therefore by subtracting the $-\log$ of these values it can be concluded that in the order of 100 to 1000 times more nitrate than Tc leached from these BFS-grout samples.

Kaplan and Coates (2007) and Kaplan et al. (2008) conducted (ad)sorption experiments with Tc and SRS saltstone. $\mathrm{K}_{\mathrm{d}}$ values can be measured by either adsorption or desorption measurements (Krupka et al. 1999). But desorption tests tend to yield larger $\mathrm{K}_{\mathrm{d}}$ values due to 
hysteresis effects (Krupka et al. 1999). Their experiments were performed on the lab benchtop exposed to air. They added Tc(VII) to saltstone (45\% slag), vault concrete (10\% slag), or 50-yearold aged cement ( $0 \%$ slag). The measured $\mathrm{Tc} \mathrm{K}_{\mathrm{d}}$ values ranged from 0.8 to $91 \mathrm{~mL} / \mathrm{g}$.

Langton (1988) conducted a field study with 55-gal slag saltstone sample containing Tc and nitrate (Figure 5 and Figure 6). Langton (1988) measured Tc and nitrate leachate for 2.5 years that came from slag-cement (Mix 3) and a slag-free cement (Mix 1) lysimeters (Table 11). By normalizing the data to nitrate concentration, Langton (1988) simplified a number of interpretations for the reader (Figure 6). If as above, it is assumed that nitrate moves as a conservative tracer, then it can be seen that without slag, nitrate and Tc were released at equal amounts from the slag-free cement lysimeter. When slag was present, the nitrate continued to be released, however only detection limit Tc concentrations were released from the lysimeters (Figure 6).

Table 11. Formulations for saltstone waste forms used by Langton (1988).

\begin{tabular}{|c|c|c|c|c|c|}
\hline \multicolumn{2}{|c|}{$\begin{array}{c}\text { MIX 1 } \\
\text { Cement-Based (WT\%) } \\
\end{array}$} & \multicolumn{2}{|c|}{$\begin{array}{c}\text { MIX } 2 \\
\text { Slag+Cement-Based (WT\%) }\end{array}$} & \multicolumn{2}{|c|}{$\begin{array}{r}\text { MIX } 3 \\
\text { Slag-Based (WT\%) } \\
\end{array}$} \\
\hline H Cement & 11.5 & NUCEM Slag & 15 & NUCEM Slag & 26 \\
\hline C Fly Ash & 46 & $\begin{array}{l}\text { D-Area Ash } \\
\text { (ESP) }\end{array}$ & 20 & $\begin{array}{l}\text { D-Area Ash } \\
\text { (ESP) }\end{array}$ & 26 \\
\hline Salt Solution & 42.5 & Type II Cement & 7.5 & $\mathrm{Ca}(\mathrm{OH}) 2$ & 3 \\
\hline & & $\begin{array}{l}\text { Salt Solution } \\
(29 \% \text { Salt })\end{array}$ & 57.5 & $\begin{array}{l}\text { Salt Solution } \\
(29 \% \text { Salt })\end{array}$ & 45 \\
\hline $\begin{array}{l}\text { Water to } \\
\text { Cementitious } \\
\text { Solids Ratio }\end{array}$ & 0.525 & $\begin{array}{l}\text { Water to } \\
\text { Cementitious } \\
\text { Solids Ratio }\end{array}$ & 2.68 & $\begin{array}{l}\text { Water to } \\
\text { Cementitious } \\
\text { Solids Ratio }\end{array}$ & 1.16 \\
\hline
\end{tabular}




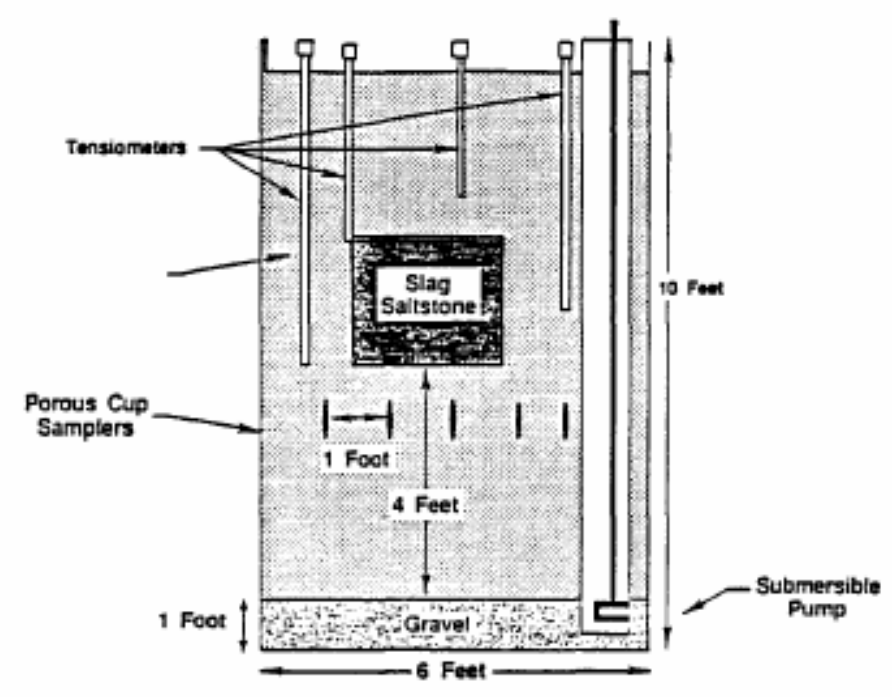

Figure 5. Schematic diagram of slag saltstone lysimeter (Langton 1988).

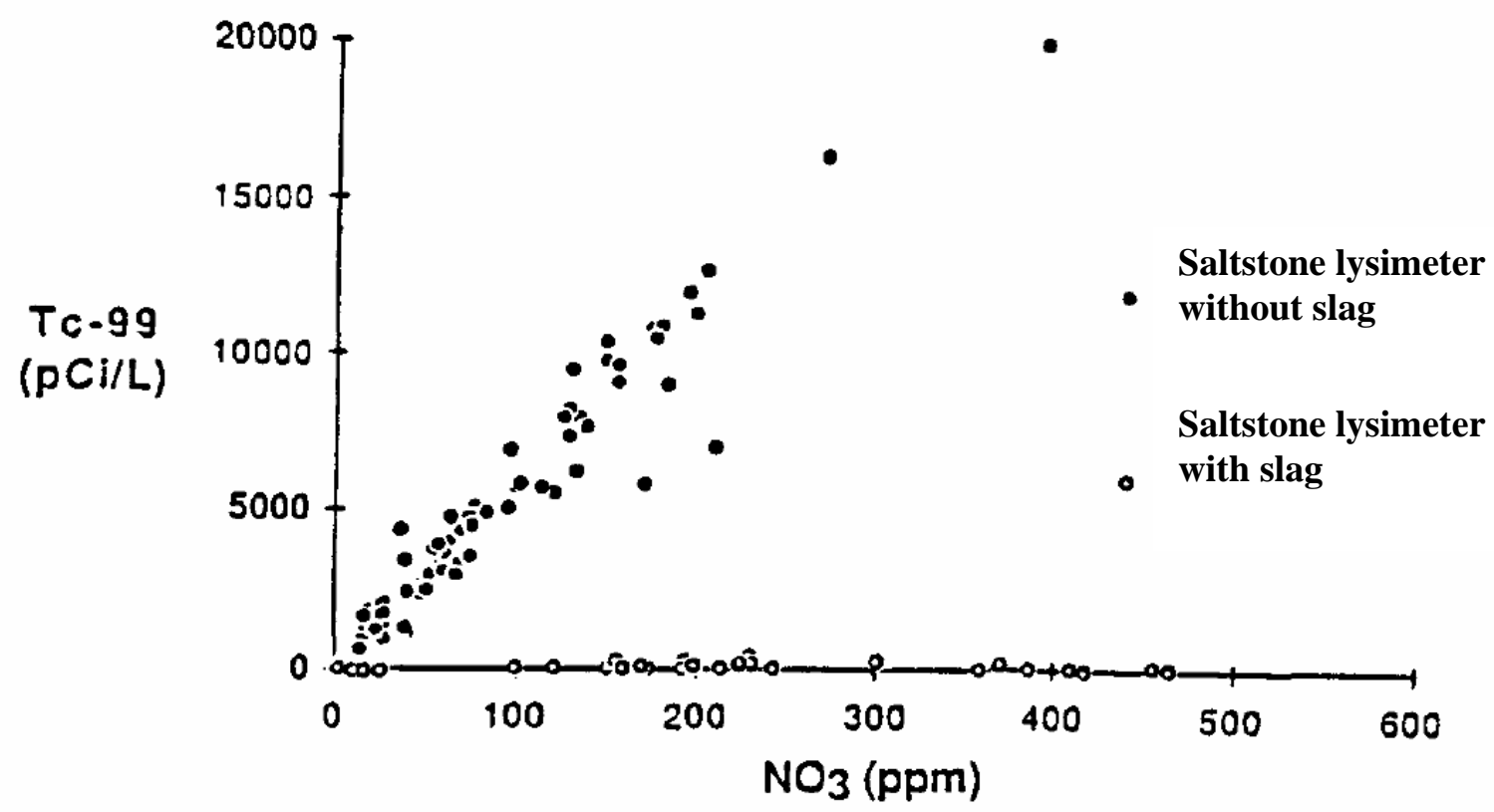

Figure 6. Tc versus nitrate concentrations for slag- and cement-based saltstone lysimeters after 2.5 years in the field (Langton 1988). 


\subsection{Tc Desorption $\mathrm{K}_{\mathrm{d}}$ Value from a Saltstone Core and other Cementitious Materials}

Almond and Kaplan (2011) measured desorption $\mathrm{K}_{\mathrm{d}}$ values from a Vault 4 saltstone sample that was collected September 2008. The grout was poured into the vault in December 2007 and the saltstone was comprised of BFS (45\%), OPC 10\%, Deliquification, Dissolution, and Adjustment (DDA) Batch 2 radioactive salt solution; 0.6 water: premix ratio, fly ash $45 \%$. The samples were cored/sampled, maintained in nitrogen, and received in olive green color with an external thin layer of light gray, indicating that a vast majority of the sample was still reduced, but that the exterior had been oxidized. Desorption leaching tests were conducted in a glovebag maintained at 30 to $60 \mathrm{ppm} \mathrm{O}_{2}$. In a glovebag, $30 \mathrm{~g}$ of ground olive green saltstone was placed in $210 \mathrm{~mL}$ of saturated $\mathrm{Ca}(\mathrm{OH})_{2}$ solution placed on a platform shaker for 20 days. They conducted an identical desorption test outside the glovebag with air sparged into the bottom of the suspension, maintaining the aqueous system at $\sim 8 \mathrm{ppm} \mathrm{O}_{2}$. Reduced suspension $\mathrm{pH}$ was 12.05, and the Eh was 140 to $400 \mathrm{mV}$. Oxidized suspension $\mathrm{pH}$ was 11.46 and the Eh was $+160 \mathrm{mV}$.

The Tc $\mathrm{K}_{\mathrm{d}}$ under the oxidizing experiment was $12 \mathrm{~mL} / \mathrm{g}$ and under reducing conditions the $\mathrm{K}_{\mathrm{d}}$ value was $139 \mathrm{~mL} / \mathrm{g}$. In the reducing experiment, the Tc $\mathrm{K}_{\mathrm{d}}$ value does not suggest that it is being controlled by a Tc-sulfide phase solubility, as has been used in defense of using low solubility values. The glovebag had very low atmospheric $\mathrm{O}_{2}$ concentrations of between 30 to $60 \mathrm{ppm}$, but the Eh of the suspensions were between 140 and $400 \mathrm{mV}$, which are in the category of suboxic. This demonstrates that only a small concentration of $\mathrm{O}_{2}$ needs to be present for oxidation of $\mathrm{Tc}(\mathrm{IV})$ to occur at the high $\mathrm{pH}$ levels of these systems. Another important point to make is that these samples were not fully reduced. A fully reduced sample would be dark black, not olive green. As such, the solid sample and the aqueous system was slightly oxidized. As such, it is not surprising that greater aqueous $\mathrm{Tc}$ concentrations than $\mathrm{TcS}_{\mathrm{x}}$-solubility were detected in these experiments.

The results from the desorption experiments with the Tc-amended cementitious materials by Lilley (2010), as discussed in Section 3.0, are also included in Table 12 for comparison. Tc $K_{d}$ values increased with slag content. As discussed, Lilley (2010) did not establish steady state in these studies and it appears that the amount of Tc sorption would have increased with contact time; this is more apparent for the saltstone with $10 \%$ and $45 \%$ slag content and less apparent for the saltstone with $95 \%$ slag content. 
Table 12. Sorption and diffusion measurements and calculated sorption coefficients for Tc(IV) and Tc(VII) with cementitious materials.

\begin{tabular}{|c|c|c|c|c|c|c|c|}
\hline & Reference & Cementitious Materials & Experimental Conditions & $\mathbf{p H}$ & Eh (mV) & $\begin{array}{l}\text { Effective } \\
\text { Diffusion } \\
\left(D_{e}\right. \\
\left.\mathrm{cm}^{2} / \mathrm{s}\right)\end{array}$ & $K_{\mathrm{d}}^{\mathrm{d}}(\mathrm{mL} / \mathrm{g})$ \\
\hline 1 & $\begin{array}{l}\text { Bayliss et al. } \\
(1992)\end{array}$ & $\begin{array}{l}\text { Ordinary Portland } \\
\text { Cement }\end{array}$ & $\begin{array}{l}\text { 1g: } 50 \mathrm{~mL} \text {; Added Tc(IV); Nitrogen } \\
\text { and hydrogen glovebox; non-saline } \\
\text { aqueous Sodium dithionite added }\end{array}$ & 13.1 & -228 & & $6000 \mathrm{Tc}(\mathrm{IV})$ \\
\hline 2 & $\begin{array}{l}\text { Bayliss et al. } \\
(1992)\end{array}$ & $\begin{array}{l}\text { Ordinary Portland } \\
\text { Cement }\end{array}$ & $\begin{array}{l}\text { 1g: } 50 \mathrm{~mL} \text {; Added Tc(IV); Nitrogen } \\
\text { and hydrogen glovebox; saline } \\
\text { aqueous Sodium dithionite added }\end{array}$ & 12.6 & -264 & & $1000 \mathrm{Tc}(\mathrm{IV})$ \\
\hline 3 & ANDRA (2005) & $\mathrm{CEM} \mathrm{I/V}$ and $\mathrm{CSH}$ & & 9.9-12.1 & & & 760-3,700 Tc(IV) \\
\hline 4 & $\begin{array}{l}\text { Gilliam et al. } \\
(1988)\end{array}$ & $\begin{array}{l}\text { Tested } 6 \text { different types } \\
\text { of slags: ( } 20 \% \text { slag, } \\
20 \% \text { fly ash, } 20 \% \text { OPC, } \\
40 \% \text { HMS filter })\end{array}$ & $\begin{array}{l}\text { ANSI 16.1; Calculated } \mathrm{K}_{\mathrm{d}} \text { based on } \\
\text { Leachability Index (which is } \approx-\log \text { of } \\
\mathrm{D}_{\mathrm{e}} \text { ). }\end{array}$ & & Ave $=-250$ & & $\begin{array}{l}\text { Cleveland } \sim 1000 \\
\text { Japan }=\sim 100 \\
\text { Japan-a } \sim 1000 \\
\text { Cleveland-b } \sim 1000 \\
\text { Cleveland }=1000 \\
\text { Sparrow } \mathrm{Pt} \sim 1000 \\
\text { Avg of } 6 \sim 1000\end{array}$ \\
\hline 5 & Serne et al (1992) & $\mathrm{T}-106 \mathrm{AN}^{\mathrm{a}}(47.5 \%$ slag $)$ & $\begin{array}{l}\text { ANSI/ANS } 16.1 ; \text { oxidizing conditions, } \\
\mathrm{D}_{\mathrm{e}} \text { nitrate }=10^{-8} \mathrm{~cm}^{2} / \mathrm{s}\end{array}$ & & & $10^{-8}$ & $\sim 1^{\mathrm{b}}$ \\
\hline 6 & Serne et al (1992) & DSSF (47\% slag) & $\begin{array}{l}\text { ANSI/ANS } 16.1 ; \text { oxidizing conditions, } \\
D_{\mathrm{e}} \text { nitrate }=10^{-8} \mathrm{~cm}^{2} / \mathrm{s}\end{array}$ & & & $10^{-8}$ & $\sim 1^{\mathrm{b}}$ \\
\hline 7 & Langton (1988) & $\begin{array}{l}\text { Saltstone Mix } 2(25 \% \\
\text { slag) }{ }^{a}\end{array}$ & $\begin{array}{l}\text { ANSI/ANS } 16.1 ; \text { oxidizing conditions, } \\
D_{\mathrm{e}} \text { nitrate }=10^{-9} \mathrm{~cm}^{2} / \mathrm{s}\end{array}$ & & & $10^{-12}$ & $\sim 1000^{b}$ \\
\hline 8 & Langton (1988) & $\begin{array}{l}\text { Saltstone Mix } 2(25 \% \\
\text { slag) }{ }^{a}\end{array}$ & $\begin{array}{l}\text { ANSI/ANS } 16.1 ; \text { oxidizing conditions, } \\
D_{\mathrm{e}} \text { nitrate }=10^{-7} \mathrm{~cm}^{2} / \mathrm{s}\end{array}$ & & & $10^{-12}$ & $\sim 100,000^{b}$ \\
\hline 9 & Langton (1988) & Saltstone without slag & $\begin{array}{l}\text { ANSI/ANS } 16.1 ; \text { oxidizing } \\
\text { conditions, } D_{\mathrm{e}} \text { nitrate }=10^{-9} \mathrm{~cm}^{2} / \mathrm{s}\end{array}$ & & & $10^{-9}$ & $\sim 1^{\mathrm{b}}$ \\
\hline 10 & Brodda (1988) & $\begin{array}{l}\text { Portland, aluminous } \\
\text { cement blast furnace } \\
\text { cement }\end{array}$ & $\begin{array}{l}\text { ANSI/ANS } 16.1 ; \mathrm{Cl} \text { leached by a } \\
\text { factor of }>100 \text { faster than Tc }\end{array}$ & & & & $\sim 100$ \\
\hline 11 & $\begin{array}{l}\text { Tallent et al. } \\
\text { (1988) }\end{array}$ & $70 \%$ slag $/ 25 \%$ cement & $\begin{array}{l}\text { ANSI/ANS } 16.1 \text {; leachability index } \\
(\mathrm{LI}) \approx-\log \text { of } \mathrm{D}_{\mathrm{e}}: \mathrm{Tc} \mathrm{LI}=9.3 \& \mathrm{NO}_{3} \\
\mathrm{LI}=7.8\end{array}$ & & & & $\sim 100$ \\
\hline
\end{tabular}




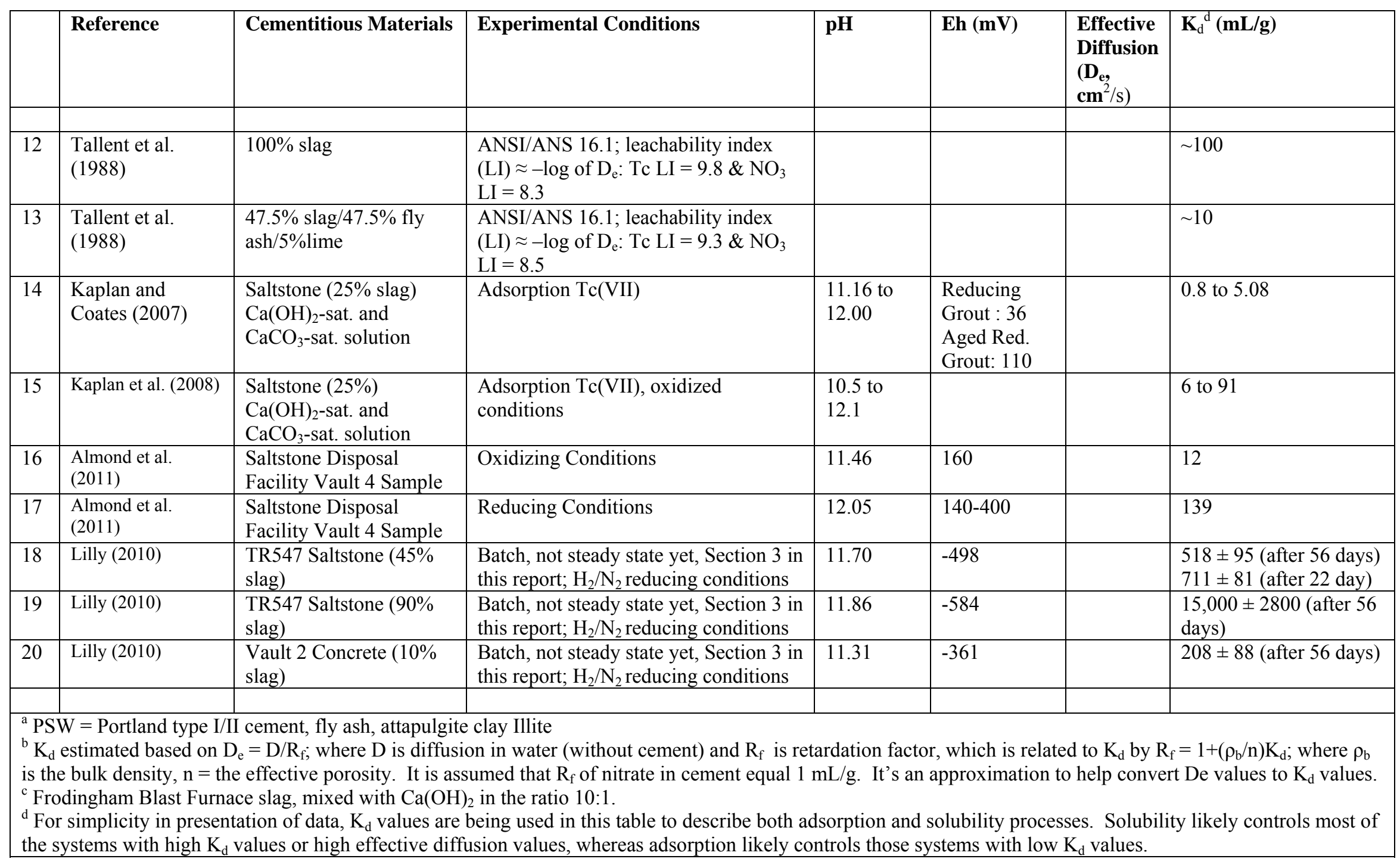




\subsection{Conclusions}

Research and a literature study were completed to investigate the behavior of Tc within cementations materials. From a combination of these studies, it is apparent that Tc can be reduced by BFS under laboratory and field conditions. These results point to the ability of saltstone containing BFS under anaerobic conditions to generate a reducing environment and to effectively immobilizing $\mathrm{Tc}$ as $\mathrm{TcS}_{\mathrm{x}}$ or $\mathrm{TcO}_{2} \bullet \mathrm{xH}_{2} \mathrm{O}$.

This work largely reinforced our conceptual model of the shrinking core but more importantly provided some clarity regarding process kinetics, mechanisms, and input values for future detailed modeling. The shrinking core model in itself is devoid of geochemical mechanisms, this study permitted us to add more geochemical detail to this model. The shrinking core model describes the existence of an oxidized outer layer of concrete surrounding a shrinking core of reducing intact saltstone. A sharp boundary between the two zones moves slowly inward, resulting in oxidation of $\mathrm{Tc}(\mathrm{IV})$. Tc(IV) initially exists as $\mathrm{Tc}_{2} \mathrm{~S}_{7(\mathrm{~s})}$ in the wasteform, then in the presence of $\mathrm{O}_{2}$ it relatively quickly converts to $\mathrm{TcO}_{2} \cdot \mathrm{xH}_{2} \mathrm{O}_{(\mathrm{s})}$, (Shuh et al. 2000) before in turn rapidly oxidizing to $\mathrm{TcO}_{4}^{-}(\mathrm{aq})$, the specie that enters the aqueous phase. As $\mathrm{TcO}_{4}^{-}(\mathrm{aq})$, it diffuses through the solution in the pores and micro cracks in the cementitious material. The solubility of $\mathrm{TcO}_{2} \cdot \mathrm{xH}_{2} \mathrm{O}_{(\mathrm{s})}$ (at $\mathrm{pH} 12.5$ at $-400 \mathrm{mV}$ ) is $10^{-7} \mathrm{M}$, which exceeds the maximum contamination limit (MCL) for ${ }^{99} \mathrm{Tc}$ set at $900 \mathrm{pCi} / \mathrm{L}$ or $5 \times 10^{-10} \mathrm{M}$. Therefore, once the $\mathrm{O}_{2}$ front initially arrives, the conversion from $\mathrm{Tc}_{2} \mathrm{~S}_{7(\mathrm{~s})}$, not the reduction, to $\mathrm{TcO}_{2} \bullet \mathrm{xH}_{2} \mathrm{O}_{(\mathrm{s})}$ will promote $\mathrm{Tc}$ concentrations to exceed the MCL by three orders of magnitude (i.e., the solubility of the latter exceeds the MCL by three orders of magnitude). As the Eh continues to increase from -400 to $-200 \mathrm{mV}$ at $\mathrm{pH} 12.5$, the solubility of $\mathrm{TcO}_{2} \bullet \mathrm{xH}_{2} \mathrm{O}_{(\mathrm{s})}$ will increase to $>10^{-1} \mathrm{M} \mathrm{Tc}$.

Atkins and Glasser (1992) report that under natural and experimental conditions it takes several months to obtain steady state reducing conditions within a cementitious material. This long duration is a result of slow reaction kinetics associated with various chemical and mineralogical transformations that take place within cement, but also because of the need for slag particles to undergo hydrolysis and to release $\mathrm{S}^{2-}$, a reducing agent, into the aqueous phase. Recent batch sorption experiments (Lilley 2010) with slag formulations approaching that of the Saltstone facility, TR547 (45\% slag), were in contact with Tc for approximately two months, short of the predicted greater than 18 months required to obtain steady state (Atkins and Glasser 1992). The greatest $K_{d}$ value measured with the TR547 saltstone was $711 \pm 81 \mathrm{~mL} / \mathrm{g}$, but presumably the $\mathrm{K}_{\mathrm{d}}$ would have continued to increase as the slag had more time to hydrolyze, releasing aqueous $\mathrm{S}^{2-}$. Similarly, the TR545 $(90 \% \mathrm{slag})$ saltstone, which had a maximum $\mathrm{K}_{\mathrm{d}}$ of $14,445 \pm 2,800 \mathrm{~mL} / \mathrm{g}$, also appeared not to have reached steady state (Figure 2)

A sharp boundary will likely form between the oxidized and reduced zones because the kinetics of the oxidation reaction are rapid (Shuh et al. 2000; Lukens et al. 2005). Finally, site specific measurements support assigning $K_{d}$ values at three points in this field:

- Oxidized zone, where the primary sorption mechanism is by anion exchange: (measured $\mathrm{Eh}=450, \mathrm{pH} 11.5) \mathrm{K}_{\mathrm{d}}=0.8 \mathrm{~mL} / \mathrm{g}$ (primary data support is in Kaplan 2010)

- Reduced zone, where the primary sorption mechanism is Tc(IV) phase solubility: (measured $\mathrm{Eh}=-585,11.7), \mathrm{K}_{\mathrm{d}}=1000 \mathrm{~mL} / \mathrm{g}$ (primarily data supported is in Kaplan 2010, also Figure 2 and Table 12) 
- Furthermore, it is possible to assign a third $\mathrm{K}_{\mathrm{d}}$ value just ahead of the $\mathrm{O}_{2}$ front, but within the reducing zone: (measured $\mathrm{Eh}=250, \mathrm{pH} 12.1), \mathrm{K}_{\mathrm{d}}=139$ (Almond and Kaplan 2011).

As the boundary moves into the saltstone over time, appreciable oxidation of Tc(IV) species to $\mathrm{Tc}$ (VII) will occur in this region facilitating the solubility of Tc into the pore solution where it is released into the aqueous phase.

\subsection{Reference}

Almond, P. M., D. I. Kaplan. 2011. Distribution Coefficients $\left(\mathrm{K}_{\mathrm{d}}\right)$ Generated from a Core Sample Collected from the Saltstone Disposal Facility. SRNL-STI-2010-00667. Savannah River National Laboratory, Aiken, SC.

Angus, M. J., and F. P. Glasser. 1985. The Chemical Environment in Cement Matrices. Scientific Basis for Nuclear Waste Management IX. Mat. Res. Soc. Symp. Proc. 50: 547-556.

ANDRA, 2005. Refentiel de Comportement des Radionuclidedes et des Toxiques Chimiques d'un Stockage dans le Calovo-Oxfordien Jusqu'a L'homme, Site de Meuse/Haute-Marne, Tome 1/2: Chapitres 1 a 4, Dossier 2005 Argile.

ANSI/ANS-16.1-1986, Measurement of the Leachability of Solidified Low-Level Radioactive Wastes by a Short-Term Test Procedure. An American National Standard, American Nuclear Society, LaGrange Park, IL (April 14, 1986).

Allen, P. G., G. S. Siemering, D. K. Shuh, J. J. Bucher, N. M. Edelstein, C. A. Langton, S. B. Clark, T. Teich, and M. A. Denecke. 1997. Technetium Speciation in Cement Waste Forms Determined by X-ray Absorption Fine Structure Spectroscopy. Radiochim. Acta 76:77-86.

Atkins, M., and F. P. Glasser. 1992. Application of Portland Cement-Based Materials to Radioactive Waste Immobilization. Waste Management. 12: 105-132.

Bayliss, S., A. Haworth, R. McCrohon, A. D. Moreton, P. Oliver, M. J. Pilkington, A. J. Smith, and J. L. Smith-Briggs. 1992. Mat. Res. Soc. Symp. Proc. 257: 641-648.

Brodda, B.G., 1988. Leachability of Technetium from Concrete. Sci. Total Environ. 69: 319-345.

Criscenti, L., and R. J. Serne. 1990. Thermodynamic Modeling of Cement/groundwater Interactions as a Tool for Long-term Performance Assessment. Mat. Res. Soc. Symp. Proc. 176. 81: 81-88.

Gillian, T. M., R. D. Spence, B. S. Evans-Brown, I. L. Morgan, J. L. Shoemaker, and W. D. Bostick. 1990. Solidification/stabilization of Technetium in Cement-based Grouts. J. Hazard. Mater. 1990. 24: 189-197.

Kaplan, D.I., T. Hang, and S. E. Aleman. 2005. Estimated Duration of the Reduction Capacity within a High-Level Waste Tank. WSRC-RP-2005-01674, Revision 0. Washington Savannah River Company, Aiken, SC. 
Kaplan, D. I., and J. T. Coates. 2007. Partitioning of Dissolved Radionuclides to Concrete under Scenarios Appropriate for Tank Closure Performance Assessments. WSRC-STI-2007-00640, Rev. 0. Washington Savannah River Company, Aiken, SC 29808.

Kaplan, D. I., Coates, J. M., Siegfried, M, Roberts, K., Serkiz, S. 2008. Saltstone and Radionuclide Interactions: Technetium Sorption and Desorption, Saltstone Reduction Capacity, and Radionuclide Sorption $\left(\mathrm{K}_{\mathrm{d}}\right)$ Value. SRNS-STI-2008-00045. Savannah River National Laboratory, Aiken, SC.

Krupka, K. M., D. I. Kaplan, G. Whelan, R. J. Serne, and S. V. Mattigod. 1999. Understanding Variation in Partition Coefficient, $K_{d}$, Values. Volume 1: The $K_{d}$ Model, Methods of Measurement, and Application of Chemical Reaction Codes. EPA 402-R-99-004A. Office of Air and Radiation, Office of Solid Waste and Emergency Response, U.S. Environmental Protection Agency, Washington, DC. (http://www.epa.gov/radiation/cleanup/partition.htm)

Langton, C. A. 1988. Slag-based Saltstone Formulations. Mat Res. Soc. Sump. Proc. 112: 61-70.

Lilley, M. 2010. Determination of Sorption Coefficients for Neptunium, Plutonium, Iodine, and Technetium in Engineered and Natural Systems under Oxidizing and Reducing Conditions. Masters Degree Thesis. Clemson University, Clemson, SC.

Lukens, W. W.; Bucher, J. J.; Shuh, D. K.; Edelstein, N. M., Evolution of Technetium Speciation in Reducing Grout. Environmental Science \& Technology. 2005, 39, (20), 8064-8070.

Powell, B. A., Fjeld, R. A., Coates, J. T., Kaplan, D. I., Serkiz, S. M. 2002. Plutonium oxidation state geochemistry in the SRS subsurface environment. WSRC-TR-2003-00035. Savannah River National Laboratory, Aiken, SC.

Roberts, K. A. and D. I Kaplan. 2008. Carbon-14 Geochemistry at Savannah River Site. SRNSSTI-2008-00445. Savannah River National Laboratory, Aiken, SC.

Serne,R. J., R. O. Lokken, and L. J. Criscenti. 1992. Characterization of Grouted Low-level Waste to Support performance Assessment. Waste Management. 12:271-287.

Shuh, D. K., N. Kaltsoyannis, J. J. Bucher, N. M. Edelstein, S. B. Clark, H. Nitsche W. Lukens, W. -S. Yang and J. C. Bryan. 1994. Environmental Applications of XANES: Speciation of Tc in Cement after Chemical Treatment and Se after Bacterial Uptake. Mat. Res. Soc. Symp. Proc. 344: 323-328.

Shuh, D. K., N. M. Edelstein, C. J. Burns, W. W. Lukens, J. J. Bucher, M. G. Fickes, B. L. Scott. 2000. Research Program to Investigate the Fundamental Chemistry of Technetium. EMSP60296. Lawrence Berkeley National Laboratory. Berkeley, CA.

Smith, R. W., and J. C. Walton. 1993. The Role of Oxygen Diffusion in the Release of Technetium from Reducing Cementitious Waste Forms. Mat Res. Soc Symp Proc. 294: 247253. 
Tallent, O.K., E. W. McDaniel, G. D. Del Cul, D. E. Dodson, and D. R. Trotter. 1988. Immobilization of Technetium and Nitrate in Cement-Based Materials. Mat. Res. Soc. Symp. Proc. 112:23-32. 


\section{Distribution:}

\section{Savannah River Site}

P. M. Almond, 773-43A - Rm.227

A. B. Barnes, $999-\mathrm{W}-\mathrm{Rm} .336$

H. H. Burns, 773-41A - Rm.214

B. T. Butcher, 773-43A - Rm.212

L. B. Collard, 773-43A - Rm.207

A. D. Cozzi, 999-W - Rm.337

D. A. Crowley, 773-43A - Rm.216

S. D. Fink, 773-A - Rm.B112

G. P. Flach, 773-42A - Rm.211

B. J. Giddings, 786-5A - Rm.5

C. C. Herman, 999-W - Rm.344

R. A. Hiergesell, 773-43A - Rm.218

G. K. Humphries, 705-3C - Rm.206

P. R. Jackson, 703-46A - Rm. 223

D. I. Kaplan, 773-43A - Rm.215

C. A. Langton, 777-42A - Rm.219

D. Li, 999-W - Rm.336

S. L. Marra, 773-A - Rm.A-230

F. M. Pennebaker, 773-42A - Rm.146

M. A. Phifer, 773-42A - Rm.252

M. M. Reigel, 999-W - Rm.404

K. A. Roberts, 773-43A - Rm.225

K. H. Rosenberger, 705-1C - Rm.33b

F. G. Smith, III 773-42A - Rm.178

K. H. Subramanian, 766-H - Rm.2204

Clemson University, 342 Computer Court, Anderson SC 29625

B. A. Powell

M. Lilley

( 1 file copy \& 1 electronic copy), 773-43A - Rm.213 